ARTICLE

Received 14 Jul 2014 | Accepted 1 Apr 2015 | Published 11 May 2015

DOI: $10.1038 /$ ncomms 8100

\title{
Evidence for photochemical production of reactive oxygen species in desert soils
}

Christos D. Georgiou1, Henry J. Sun ${ }^{2}$, Christopher P. McKay ${ }^{3}$, Konstantinos Grintzalis ${ }^{1}$, loannis Papapostolou? Dimitrios Zisimopoulos ${ }^{1}$, Konstantinos Panagiotidis ${ }^{1}$, Gaosen Zhang ${ }^{4}$, Eleni Koutsopoulou ${ }^{5}$, George E. Christidis ${ }^{6}$ \& Irene Margiolaki ${ }^{1}$

The combination of intense solar radiation and soil desiccation creates a short circuit in the biogeochemical carbon cycle, where soils release significant amounts of $\mathrm{CO}_{2}$ and reactive nitrogen oxides by abiotic oxidation. Here we show that desert soils accumulate metal superoxides and peroxides at higher levels than non-desert soils. We also show the photogeneration of equimolar superoxide and hydroxyl radical in desiccated and aqueous soils, respectively, by a photo-induced electron transfer mechanism supported by their mineralogical composition. Reactivity of desert soils is further supported by the generation of hydroxyl radical via aqueous extracts in the dark. Our findings extend to desert soils the photogeneration of reactive oxygen species by certain mineral oxides and also explain previous studies on desert soil organic oxidant chemistry and microbiology. Similar processes driven by ultraviolet radiation may be operating in the surface soils on Mars.

\footnotetext{
${ }^{1}$ Department of Biology, University of Patras, Patras 26504, Greece. ${ }^{2}$ Desert Research Institute, Las Vegas, Nevada 89119, USA. ${ }^{3}$ NASA Ames Research Center, Moffett Field, California 94035, USA. ${ }^{4}$ Cold and Arid Regions Environmental and Engineering Research Institute, Chinese Academy of Sciences, Lanzhou 73000, China. ${ }^{5}$ Laboratory of Electron Microscopy and Microanalysis, University of Patras, Patras 26500, Greece. ${ }^{6}$ Department of Mineral Resources Engineering, Technical University of Crete, Chania 73100, Greece. Correspondence and requests for materials should be addressed to C.D.G. (email: c.georgiou@upatras.gr).
} 
n most ecosystems, microorganisms carry out mineralization of soil organic matter. In desert soils, however, non-biological and biological organic decomposition can be comparable in magnitude. For example, soils from the Atacama Desert, Chile, can oxidize D-alanine and L-glucose at significant rates, although terrestrial organisms do not utilize these enantiomers ${ }^{1,2}$. In the Mojave Desert, California, nitrogen oxide (NOy) gases are emitted from desiccated soils ${ }^{3}$ at rates comparable to wet soils only if the soils are irradiated by sunlight. In other arid and semiarid locations, photochemical degradation reportedly accounts for $60 \%$ of plant litter decomposition ${ }^{4}$. Studies on the photochemical oxidation of xenobiotic organic carbon (herbicides, insecticides and pesticides) in agricultural soils suggested that ${ }^{1} \mathrm{O}_{2}$ generated by sunlight via the photosensitization of soil organics (and possibly of $\mathrm{Ti}$ - and $\mathrm{Zn}$-oxides) to be the main oxidant ${ }^{5}$. The involvement of other reactive oxygen species (ROSs) such as superoxide $\left(\mathrm{O}_{2}{ }^{-}\right)$and hydroxy $\left({ }^{\circ} \mathrm{OH}\right)$ radical has been hypothesized as well ${ }^{6-11}$. $\mathrm{OH}$ is postulated to result indirectly from the reaction of water with humic substances in the excited triplet state or from degradation of $\mathrm{H}_{2} \mathrm{O}_{2}$ by transition metal $\left(\mathrm{Me}_{\mathrm{tr}}\right)$ cations such as $\mathrm{Fe}^{3+}$ via a photo-Fenton reaction ${ }^{10}$. However, the photochemical oxidative process and its components are not well understood because of a lack of methods for the detection of the involved ROS in soils and their very short life ( 1 ns to $1 \mu$ s (ref. 12)).

Photogenerated ROS have been identified in laboratory studies on mineral oxides (mainly $\mathrm{TiO}_{2}$ ) exposed to ultraviolet radiation: atomic oxygen radical anion $\left(\mathrm{O}^{-}{ }^{-}\right)$, ozone radical anion $\left(\mathrm{O}_{3}{ }^{-}\right.$, and possibly $\left.\mathrm{O}_{4}^{-}\right), \mathrm{O}_{2}^{-}$and $\mathrm{OH}^{13-15}$. The postulated process in these studies involves ultraviolet-induction of electron mobilization from the oxide surface and its subsequent capture by $\mathrm{O}_{2}$ to form oxygen radical surface adsorbates ${ }^{16}$. This photoinduced mechanism is also supported by the previously shown generation of $\mathrm{O}_{2}{ }^{-}$in ultraviolet-exposed plagioclase feldspars ${ }^{17}$. Singlet oxygen $\left({ }^{1} \mathrm{O}_{2}\right)$ also has been identified ${ }^{18,19}$ and may oxidize soil organics via intermediate oxidant products but is not adsorbed on mineral surfaces because it is uncharged. Degradation of organic compounds, mainly via $\mathrm{OH}$, can be catalysed by the photochemistry (via reduction) of iron (III) species such as $\mathrm{Fe}(\mathrm{OH})_{3}, \mathrm{FeOOH}$ and $\mathrm{Fe}_{2} \mathrm{O}_{3}$ (ref. 20), besides $\mathrm{TiO}_{2}$-mineral oxides.

Here we show that metal superoxides and peroxides accumulate in topsoils of the Atacama and Mojave deserts (at midsummer sunlight irradiance $800-1,000 \mathrm{~W} \mathrm{~m}^{-2}$ ) at a 10 -fold higher level than in a non-arid control site. Moreover, we show that desiccated and aqueous desert soils photogenerate equimolar $\mathrm{O}_{2}{ }^{-}$adsorbates and $\mathrm{OH}$, respectively, and also that the reactivity of desert soils is associated with the generation of $\cdot \mathrm{OH}$ and the concomitant decrease of soil $\mathrm{H}_{2} \mathrm{O}_{2}$ in their aqueous extracts in the dark, possibly via the Fenton reaction due to the presence of $\mathrm{Me}_{\mathrm{tr}}$ in these soils. For this study, new methods enable the identification of soil $\mathrm{O}_{2}^{-}, \mathrm{H}_{2} \mathrm{O}_{2}$ and ${ }^{-} \mathrm{OH}$. These methods are not yet suitable, however, for in situ studies on the seasonal and soil depth-dependent formation rates of detected soil oxidants. Moreover, their specificity restricts the evaluation of only a fraction of the photogenerated ROS involved in the oxidative desert soil chemistry. Although the elucidation of the entire model of desert soil ROS photogeneration is not possible with the available methods, they unveil some key steps as they take place by a photo-induced electron transfer mechanism. In addition, our selected soil desert sites are among the most studied of all the world's arid locations ${ }^{1,21,22}$, and thus provide a good basis for considering the environmental effects of aridity on the photochemical production of ROS in desert soils.

\section{Results}

Detection and stability soil $\mathrm{O}_{2}^{-}$/peroxides and detection of $\mathbf{M e}_{\mathbf{t r}}$. We extracted soil metal superoxides as $\mathrm{O}_{2}^{-}{ }^{-}$from desiccated Atacama and Mojave Desert topsoils by acetonitrile and quantified fluorometrically by a modified hydroethidine (HE)based assay ${ }^{23,24}$, and the identity of $\mathrm{O}_{2}^{-}$and validity of the $\mathrm{HE}$ based assay were verified by a second assay ${ }^{25,26}$, a modification of the superoxide dismutase (SOD)-inhibited equimolar reduction of cyt. $c$ by $\mathrm{O}_{2}^{-}$(Methods, Supplementary Methods). The methodological baseline for $\mathrm{O}_{2}{ }^{-}$detection was determined in $\mathrm{H}_{2} \mathrm{O}$-prewashed and dried soil, a treatment that destroys $\mathrm{O}_{2}{ }^{-}$by dismutation $^{12}$ :

$$
2 \mathrm{O}_{2}^{-}+2 \mathrm{H}_{2} \mathrm{O} \rightarrow 2 \mathrm{OH}^{-}+\mathrm{H}_{2} \mathrm{O}_{2}+\mathrm{O}_{2}
$$

Soil metal peroxides (peroxides/hydroperoxides) were quantified upon aqueous extraction as $\mathrm{H}_{2} \mathrm{O}_{2}$ (their hydrolysis product shown in reactions 2-4; refs 27,28):

$$
\begin{gathered}
\mathrm{Me}_{2}^{+} \mathrm{O}_{2}^{2-}+2 \mathrm{H}_{2} \mathrm{O} \rightarrow 2 \mathrm{Me}^{+} \mathrm{OH}^{-}+\mathrm{H}_{2} \mathrm{O}_{2} \\
\mathrm{Me}^{2+} \mathrm{O}_{2}^{2-}+2 \mathrm{H}_{2} \mathrm{O} \rightarrow \mathrm{Me}^{2+}\left(\mathrm{OH}^{-}\right)_{2}+\mathrm{H}_{2} \mathrm{O}_{2} \\
\mathrm{MeO}_{2} \mathrm{H}+\mathrm{H}_{2} \mathrm{O} \rightarrow \mathrm{MeOH}+\mathrm{H}_{2} \mathrm{O}_{2}
\end{gathered}
$$

Soil metal peroxides can be present, however, in mixture with metal superoxides that on aqueous extraction also release $\mathrm{H}_{2} \mathrm{O}_{2}$ (reaction 1). Thus, the extracted soil $\mathrm{H}_{2} \mathrm{O}_{2}$ is the sum of two fractions that can be quantitatively differentiated. The first $\mathrm{H}_{2} \mathrm{O}_{2}$ fraction results from equimolar hydrolysis of metal peroxides (equations 2-4). The second is differentiated from the first because it results from dismutation of $\times 2$ molar metal superoxides (equation 1). Total soil $\mathrm{H}_{2} \mathrm{O}_{2}$ extracted from metal superoxides plus peroxides was quantified by a modification of the $\mathrm{Fe}^{2+}$-xylenol orange assay (Methods, Supplementary Methods), using catalase as control ${ }^{29}$.

Atacama and Mojave Desert soils contained $\sim 2.0 \mathrm{nmol} \mathrm{O}_{2}{ }^{-} \mathrm{g}^{-1}$ (that is, metal superoxides). In contrast, soils from a non-arid control location contained an order of magnitude less concentration of $\sim 0.2 \mathrm{nmol} \mathrm{g}^{-1}$ (Table 1 ). However, the dry desert soil is conducive to preservation of $\mathrm{O}_{2}^{-}$, while constantly humid soils are not (because of reaction 1). Even in the deserts, given the extreme labile nature of $\mathrm{O}_{2}^{-}{ }^{-}$, only a small fraction would be

Table 1 | Soil metal superoxides, total superoxides/peroxides $\left(\mathrm{H}_{2} \mathrm{O}_{2}\right)$ and $\mathrm{Fe}^{3+}$.

Soil oxidants ${ }^{\star}$

\begin{tabular}{l} 
\\
\hline $\mathrm{O}_{2}^{-\dagger}$ \\
$\mathrm{H}_{2} \mathrm{O}_{2}$ \\
$\mathrm{Fe}^{3+\dagger}$
\end{tabular}

\begin{tabular}{cc}
\multicolumn{2}{c}{ Atacama Desert sites $^{\star}$} \\
\hline $\mathbf{1}$ & \multicolumn{1}{c}{ Yungay } \\
\hline $1.8 \pm 0.6(0.03)$ & $1.9 \pm 0.3(0.03)$ \\
$14 \pm 2(0.05)$ & $19 \pm 2(0.6)$ \\
$20 \pm 2(1.2)$ & $10 \pm 1(0.6)$
\end{tabular}

\begin{tabular}{c} 
Mojave \\
\hline Basalt \\
$2.3 \pm 0.4(0.04)$ \\
$110 \pm 9(4)$ \\
$10 \pm 3(0.6)$
\end{tabular}

Mojave Desert sites ${ }^{\star}$

+ CIMA sand

$2.0 \pm 0.3(0.03)$

$5 \pm 0.7(0.4)$

$12 \pm 2(0.6)$

$0.2 \pm 0.01(0.01)$

$0.2 \pm 0.03(0.01)$

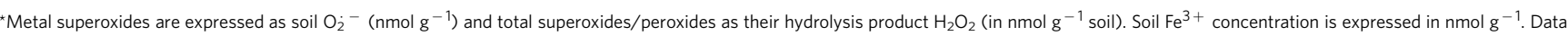
are mean values \pm standard error from at least five replicates. Numbers in parentheses are in $\mathrm{ppm}$.

$\dagger$ Values for soil $\mathrm{O}_{2}^{-}$are averages of the mean values obtained by the $\mathrm{HE}$-based and the SOD-inhibited reduction of cytochrome c-based soil $\mathrm{O}_{2}{ }^{-}$assays. For statistical comparison of both assays, the within-day $\%$ coefficient variation is $<3.7 \%$ and the variance of intermediate precision (or between day repeatability) is $<4.8 \%$. 
stabilized in soils. The Mojave and Atacama Desert soils also contain metal peroxides (Table 1) because the concentration levels of the extracted total soil $\mathrm{H}_{2} \mathrm{O}_{2}$ are 5-95 times higher than the $\mathrm{H}_{2} \mathrm{O}_{2}$ expected from the (dismutation of) the detected soil metal superoxides. The levels of $\mathrm{H}_{2} \mathrm{O}_{2}$ we detected in both Atacama Desert sites are similar to those previously reported ${ }^{1}$.

The detected soil metal superoxides and peroxides were stable even when the desiccated desert soils were heated at $200^{\circ} \mathrm{C}$ for $1 \mathrm{~h}$. This agreed with the finding that the desert soils retained $\sim 50 \%$ of their initial concentrations in metal superoxides and peroxides after storage for lyear (desiccated in the dark at $\sim 16^{\circ} \mathrm{C}$; data not shown). The extracted $\mathrm{H}_{2} \mathrm{O}_{2}$ was not stable through time, however, as almost $50 \%$ was destroyed within 1 day in the dark (Fig. 1a). This could be because of its decomposition to $\mathrm{OH}$ by co-extracted $\mathrm{Me}_{\text {tr }}$ via the Fenton reaction ${ }^{12,30}$, as supported by the identification of $\mathrm{Fe}$ and other $\mathrm{Me}_{\mathrm{tr}}$ (for example, $\mathrm{Cu}, \mathrm{Cr}, \mathrm{Co}, \mathrm{Ni}$ ) in these soils (Tables 1 and 2) and the participation of these in the Fenton reaction ${ }^{31}$. Indeed, desert soil $\mathrm{H}_{2} \mathrm{O}_{2}$ extracts generated $\mathrm{OH}$ through time (Fig. 1b, Methods, Supplementary Methods), the rate of which in the presence of soil decreased by $\sim 6$-fold probably because of $\cdot \mathrm{OH}$ scavenging by soil organics 32 and/or metal $(\mathrm{Me})$ ions (via the general reaction: $\cdot \mathrm{OH}+\mathrm{Me}^{n+} \mathrm{H}_{2} \mathrm{O} \rightarrow \mathrm{Me}^{n+} \mathrm{OH} \rightarrow \mathrm{Me}^{(n+1)+}+\mathrm{OH}^{-}$; ref. 33).

Photogeneration of soil $\mathrm{O}_{2}^{-}{ }^{-}$and ${ }^{\cdot} \mathrm{OH}$, and mineral analysis. ROS were photogenerated (by natural sunlight and ultraviolet $\mathrm{C}$ ) by desiccated soils. Before exposure soils also were washed to

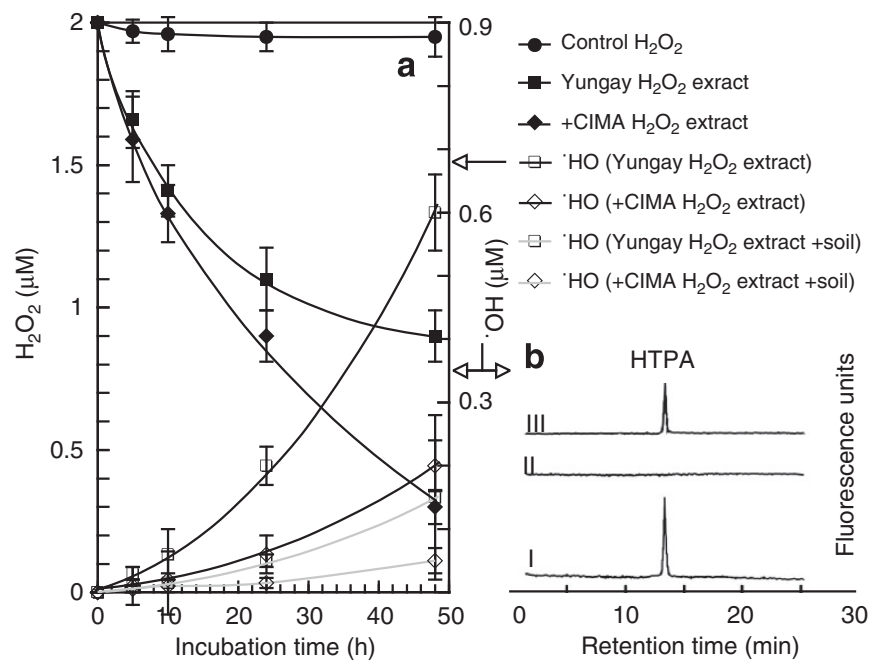

Figure 1 | Instability of acid-extracted soil $\mathrm{H}_{2} \mathrm{O}_{2}$ and generation of ${ }^{\cdot} \mathrm{OH}$. Soil $\mathrm{H}_{2} \mathrm{O}_{2}$ results from the dismutation/hydrolysis of metal superoxides/ peroxides, respectively. (a) Decreasing exponential solid line curves depict the change of $10 \mathrm{mM} \mathrm{H}_{3} \mathrm{PO}_{4}$-extracted soil $\mathrm{H}_{2} \mathrm{O}_{2}$ concentration (initially adjusted to $2 \mu \mathrm{M}$, and in the absence of the extracted soil) from the Mojave and Atacama + CIMA and Yungay sites (filled rhombs and squares), respectively, versus time, against a $2.0 \mu \mathrm{M} \mathrm{H}_{2} \mathrm{O}_{2}$ (in $10 \mathrm{mM} \mathrm{H}_{3} \mathrm{PO}_{4}$ ) control solution (filled circles). Increasing exponential line curves depict the generation (versus time) of ${ }^{\cdot} \mathrm{OH}$ in the $\mathrm{H}_{2} \mathrm{O}_{2}$ extracts from the same Mojave and Atacama sites (open rhombs and squares, respectively) in the absence and presence of soils (solid and dotted lines, respectively). (b) $\mathrm{OH}$ was detected from its reaction with TPA(added to the $\mathrm{H}_{2} \mathrm{O}_{2}$ extracts at $2 \mathrm{mM}$ ) and the equimolar production of the specific fluorescent product $\mathrm{HTPA}^{70}$. HTPA was quantified and identified fluorometrically by HPLC (I, using as controls the $\mathrm{OH}$ scavenger DMSO, II, and pure HTPA, III). Similar data (not shown) were obtained for $\mathrm{H}_{2} \mathrm{O}_{2}$ extracted from total peroxides from the other tested Atacama and Mojave Desert soil sites. Error bars designate s.d. remove any potentially interfering soil inorganics (for example, perchlorates and nitrates known to exist in these deserts ${ }^{34,35}$ ) and organics (for example, photosensitizers, ROS scavengers; Methods). Soil $\mathrm{O}_{2}{ }^{-}$and $\mathrm{H}_{2} \mathrm{O}_{2}$ (peroxides) concentrations almost doubled or tripled (above baseline; 1.5 and 0.7 nmoles $^{-1}$, respectively) during the first hour of soil irradiation (Fig. 2). A similar trend for $\mathrm{O}_{2}{ }^{-}$generated on ultraviolet-irradiated plagioclase feldspar minerals has been observed previously ${ }^{17}$. Longer irradiation (up to $6 \mathrm{~h}$ ) resulted in a concentration plateau for $\mathrm{O}_{2}{ }^{-}$(similarly for $\mathrm{H}_{2} \mathrm{O}_{2}$ ), irrespective of the radiation source (although somewhat higher for the more effective ultraviolet $\mathrm{C}$ ), which could be due to the saturation of the positively charged sites on the soil surface by the $\mathrm{O}_{2}^{-}$anion. The concentration of the soil photogenerated $\mathrm{O}_{2}{ }^{-}$(Fig. 2a) was approximately twice that of $\mathrm{H}_{2} \mathrm{O}_{2}$ (Fig. 2b). This $\mathrm{O}_{2}^{-}-\mathrm{H}_{2} \mathrm{O}_{2}$ ratio fits the stoichiometry of the dismutation of $\mathrm{O}_{2}^{-}$(reaction 1), which indicates that $\mathrm{O}_{2}{ }^{-}$is the main soil oxidant formed during sunlight/ultraviolet $\mathrm{C}$ exposure.

We analysed the mineral substrates potentially involved in the photogeneration of ROS by the Atacama and Mojave Desert and control soils both in the bulk and the clay fractions of the samples (Methods, Supplementary Methods). All the samples contained plagioclase feldspar with composition that varied from albite to labradorite. Clay minerals were most abundant in the control soil, absent from the Mojave Desert basalt, and found in traces in the remaining samples, in accordance with the Loss On Ignition data in Table 2. All the soils contain traces of Fe-Ti- and/or Fe-Mnand/or Fe-oxides and/or Ti-oxides.

It has been established that aqueous $\mathrm{TiO}_{2}$ photogenerate $\mathrm{O}_{2}{ }^{-}$ and $\mathrm{OH}^{15,36}$, the latter being photogenerated by aqueous $\mathrm{TiO}_{2}$

Table 2 | Bulk sample chemical analysis.

\begin{tabular}{|c|c|c|c|c|c|}
\hline \multirow{2}{*}{$\begin{array}{l}\text { Major elements } \\
\text { (wt \%) }\end{array}$} & \multicolumn{2}{|c|}{ Atacama desert } & \multicolumn{2}{|c|}{ Mojave desert } & \multirow[t]{2}{*}{ Control site } \\
\hline & Site 1 & Yungay & Basalt & + CIMA & \\
\hline $\mathrm{SiO}_{2}$ & 63.10 & 61.80 & 46.31 & 67.07 & 55.39 \\
\hline $\mathrm{TiO}_{2}$ & 1.11 & 0.81 & 2.48 & 0.66 & 0.53 \\
\hline $\mathrm{Al}_{2} \mathrm{O}_{3}$ & 15.98 & 13.45 & 15.80 & 14.05 & 9.21 \\
\hline $\mathrm{Fe}_{2} \mathrm{O}_{3} \mathrm{t}$ & 5.26 & 5.43 & 10.29 & 4.47 & 4.02 \\
\hline $\mathrm{MnO}$ & 0.07 & 0.07 & 0.13 & 0.05 & 0.08 \\
\hline $\mathrm{MgO}$ & 1.20 & 1.52 & 7.31 & 1.43 & 2.03 \\
\hline $\mathrm{CaO}$ & 4.55 & 5.31 & 9.28 & 3.22 & 12.13 \\
\hline $\mathrm{Na}_{2} \mathrm{O}$ & 3.99 & 3.82 & 4.09 & 3.50 & 1.32 \\
\hline $\mathrm{K}_{2} \mathrm{O}$ & 2.41 & 2.37 & 1.96 & 3.10 & 1.62 \\
\hline $\mathrm{P}_{2} \mathrm{O}_{5}$ & 0.16 & 0.16 & 0.68 & 0.17 & 0.10 \\
\hline $\mathrm{LOI}^{*}$ & 2.09 & 5.73 & 1.39 & 2.30 & 12.92 \\
\hline Total & 99.92 & 100.47 & 99.72 & 100.02 & 99.35 \\
\hline \multicolumn{6}{|c|}{ Trace elements (p.p.m.) } \\
\hline V & 172 & 164 & 215 & 76 & 78 \\
\hline $\mathrm{Cr}$ & 38 & 31 & 146 & 27 & 202 \\
\hline Co & 8 & 11 & 164 & 7 & 17 \\
\hline $\mathrm{Ni}$ & 14 & 15 & 120 & 14 & 100 \\
\hline $\mathrm{Cu}$ & 50 & 81 & 89 & 21 & 46 \\
\hline $\mathrm{Zn}$ & 50 & 79 & 89 & 47 & 105 \\
\hline $\mathrm{Rb}$ & 62 & 88 & 41 & 107 & 73 \\
\hline $\mathrm{Sr}$ & 390 & 604 & 807 & 448 & 195 \\
\hline Y & 17 & 20 & 35 & 27 & 22 \\
\hline $\mathrm{Zr}$ & 201 & 185 & 320 & 340 & 150 \\
\hline $\mathrm{Ba}$ & 681 & 744 & 599 & 711 & 230 \\
\hline La & 23 & 30 & 41 & 36 & 21 \\
\hline $\mathrm{Ce}$ & 33 & 44 & 73 & 71 & 42 \\
\hline $\mathrm{Nd}$ & 18 & 17 & 29 & 39 & 24 \\
\hline $\mathrm{Pb}$ & 18 & 39 & 16 & 33 & 48 \\
\hline Th & 7 & 9 & 5 & 12 & 8 \\
\hline
\end{tabular}




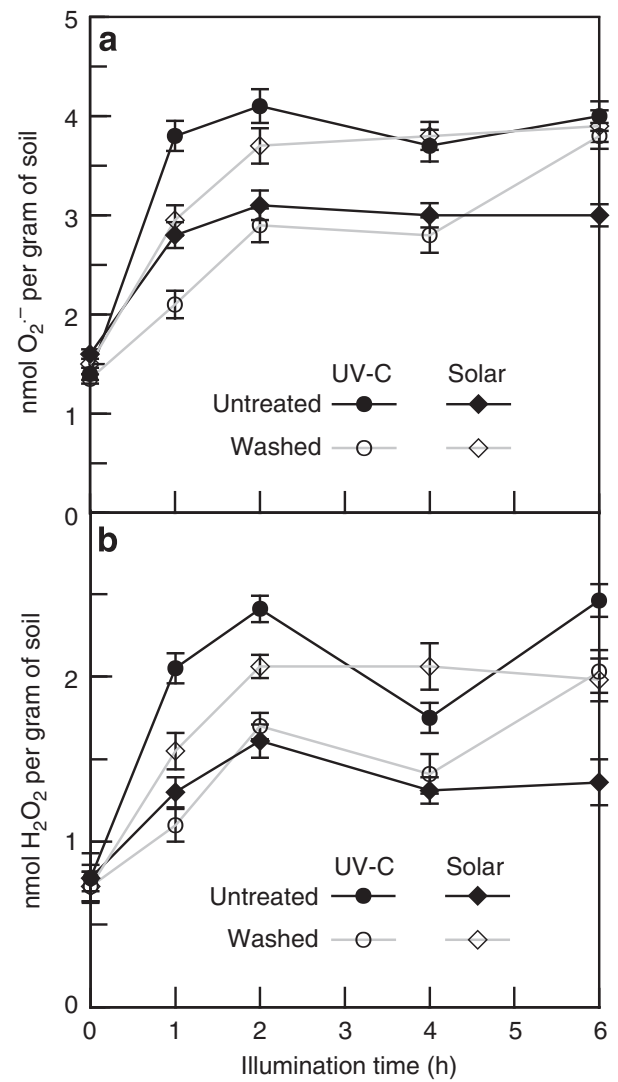

Figure 2 | Photochemical formation of ROS in desert soils. (a) $\mathrm{O}_{2}^{-}$was generated in the Mojave Desert + CIMA site (untreated or washed and then dried), which was exposed to solar (natural sunlight) and ultraviolet $C$ irradiation versus exposure time. (b) Generation of total metal superoxides/peroxides (expressed as $\mathrm{H}_{2} \mathrm{O}_{2}$ ) in the same + CIMA site under irradiation conditions as in a. Similar data (not shown) were obtained in the other tested desert/control sites. Error bars designate s.d.

films as well ${ }^{37,38}$. The presence in the tested desert soils of Ti-based transition metal oxides prompted us to investigate whether these soils photogenerate ${ }^{\circ} \mathrm{OH}$ under aqueous conditions. Here we show that both Atacama and Mojave soils $(0.2 \mathrm{~g}$, prewashed from any soluble inorganic and organic constituents) photogenerate an average of $3.2 \mathrm{~nm} \cdot \mathrm{OHh}^{-1}$ (Fig. 3) upon exposure to $180 \mathrm{~W} \mathrm{~m}^{-2} 400-700 \mathrm{~nm}$ (or $18 \%$ that of sunlight). This rate is proportional to light intensity as well (data not shown), obeying zero-order reaction rate kinetics as in aqueous $\mathrm{TiO}_{2}$ film photocatalysis ${ }^{38}$. We identified ${ }^{\circ} \mathrm{OH}$ and quantified its rate of photogeneration by a modification of the terephthalic acid (TPA)-based assay 37,38 and by the $\sim 15$-fold rate decrease caused by the $\mathrm{OH}$ scavenger dimethyl sulfoxide (DMSO; Methods). $\mathrm{OH}$ is not photogenerated by exposing a control $\mathrm{H}_{2} \mathrm{O}_{2}$ solution, given that $\mathrm{H}_{2} \mathrm{O}_{2}$ is released from metal superoxides/peroxides under aqueous conditions.

Generation of $3.2 \mathrm{nM} \cdot \mathrm{OH}$ in $1 \mathrm{~h}$ by $0.2 \mathrm{~g}$ soil exposed to $180 \mathrm{~W} \mathrm{~m}^{-2}$ or $18 \%$ that of sunlight corresponds to $\sim 1 \mathrm{nmolg}^{-1}$ for $1 \mathrm{~h}$ exposure to sunlight (see Supplementary Methods). This is similar to the plateau rate of $1.45 \mathrm{nmol} \mathrm{O}_{2}^{-} \mathrm{g}^{-1}$ that is generated by desiccated (and prewashed) desert soils after exposure to sunlight for $1 \mathrm{~h}$ (Fig. 2a). This near 1:1 molar $\mathrm{O}_{2}{ }^{-} / \mathrm{OH}$ ratio is in agreement with the mechanism of $\mathrm{TiO}_{2}$ photocatalysis ${ }^{15,36}$, which assumes equimolar $\mathrm{OH}$ and $\mathrm{O}_{2}{ }^{-}$ aqueously generated; the latter also being photogenerated in desiccated soils by the same mechanism (Fig. 4). The ratio 1:1.5 deviation from the equimolar ratio could be due to various factors

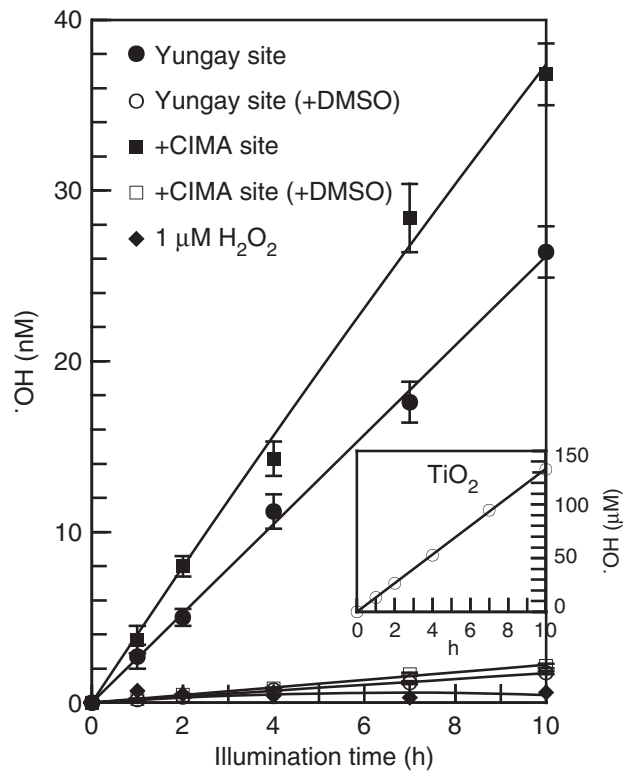

Figure 3 | Photogeneration of ${ }^{\circ} \mathrm{OH}$ by desert soils under aqueous conditions. Soils (from the Atacama Yungay site and the Mojave + CIMA site) were extensively washed and exposed to light (400-700 nm), against $\pm 100 \mathrm{mM}$ DMSO ( $\mathrm{OH}$ scavenger) and an $\mathrm{H}_{2} \mathrm{O}_{2}$ control, using commercial $\mathrm{TiO}_{2}$ (inset) as additional control, given its presence in the tested desert soils. The other tested desert/control sites gave similar data (not shown). Error bars designate s.d.

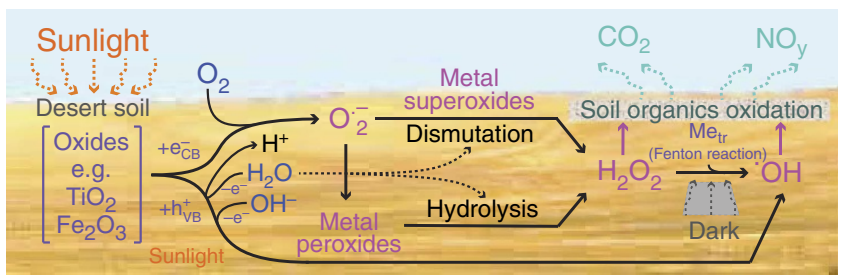

Figure 4 | Photochemical mechanism of desert soil oxidizing action. Sunlight radiation of soils generates unpaired electrons that convert $\mathrm{O}_{2}$ to $\mathrm{O}_{2}{ }^{-}$. This radical can be initially adsorbed on the surface of soils and stabilized in the long term as metal superoxides and peroxides. These can be converted under aqueous conditions (via dismutation and hydrolysis, respectively) to $\mathrm{H}_{2} \mathrm{O}_{2}$, which can be converted subsequently to hydroxyl radical $(\mathrm{OH})$ in the dark by reaction with reduced soil transition metals $\left(\mathrm{Me}_{\mathrm{tr}}\right)$. A second route of $\mathrm{OH}$ generation may involve a single electron abstraction from $\mathrm{H}_{2} \mathrm{O}$ or $\mathrm{OH}^{-}$by an $\mathrm{h}^{+}{ }_{\mathrm{VB}}$ hole (see text). $\mathrm{OH}$ (and also $\mathrm{H}_{2} \mathrm{O}_{2}$ and $\mathrm{O}_{2}^{-}$, although to a lesser degree as weak oxidants) can then oxidize soil organics possibly to $\mathrm{CO}_{2}$ and NOy.

such as the non-aqueous/aqueous generation of additional ROS species (for example, $\mathrm{O}^{-}{ }^{-}, \mathrm{O}_{3}{ }^{-}, \mathrm{O}_{4}{ }^{-}$; refs 13-15), the not accounted ultraviolet component of natural sunlight, and the possible incomplete trapping of $\mathrm{OH}$ by the assay reagent TPA. Generation of $\mathrm{OH}$ by photodissociated $\mathrm{H}_{2} \mathrm{O}_{2}$, under the employed experimental conditions, may be negligible as shown by the corresponding assay control (Fig. 3). The aqueous photogeneration of $\mathrm{OH}$ by metal oxides in desert soils also was supported by our control experiment with $\mathrm{TiO}_{2}$. Tested at a quantity equivalent to its $\mathrm{w} \%$ concentration in the soils (Table 2), $\mathrm{TiO}_{2}$ produced $\mathrm{OH}$ at $\sim 13 \mu \mathrm{Mh}^{-1}$ (Fig. 3 inset). This $\sim 4,000-$ fold higher rate compared with the desert soils is because of the very small particle size of $\mathrm{TiO}_{2}$ (photocatalysis grade, $<30 \mathrm{~nm}$ in size; ref. 39), that results in a highly disordered structure and high 
specific surface area compared with the natural $\mathrm{TiO}_{2}$ polymorphs and ilmenite (that is, $\mathrm{Fe}-\mathrm{Ti}$ oxides) found in the tested soils.

\section{Discussion}

Superoxide radical is photogenerated in desert soils (Fig. 2a) and stabilized initially as surface-saturating desiccated anionic adsorbate, given that it is the least reactive hence the most stable species formed by ultraviolet exposure ${ }^{17}$. Long-term diffusion of $\mathrm{O}_{2}^{-}$may be the subsequent stabilization process, as metal superoxides and peroxides were detected in the Atacama and Mojave Desert soils. This is in agreement with the finding that the average concentration of metal superoxides in a basalt rock (pulverized) from the Mojave Desert + CIMA field is similar to their concentration in the surrounding sand (Table 1), suggesting a long-term $\mathrm{O}_{2}{ }^{-}$diffusion inside basalt rocks. Such diffusion through soils does not occur within the short irradiation period used in our and similar studies (with labradorite), since this is considered geologically very short ${ }^{17}$.

In general, the main conditions under which stable $\mathrm{O}_{2}{ }^{-}$is formed on the surface of metal oxides and zeolites are (i) photoinduced electron transfer, (ii) direct surface-oxygen electron transfer, (iii) surface intermolecular electron transfer and (iv) the decomposition of $\mathrm{H}_{2} \mathrm{O}_{2}$ (ref. 40). The photo-induced electron transfer mechanism (Fig. 4) could involve ejection from transition or non-transition metal oxides (for example, $\mathrm{TiO}_{2}$, $\mathrm{Fe}_{2} \mathrm{O}_{3}$ (ref. 20), or $\mathrm{ZnO}$ (ref. 41), respectively) of an electron $\left(\mathrm{e}^{-} \mathrm{CB}\right)$ into its $\mathrm{CB}$ (conduction band) from its valence band (VB), and its transfer to $\mathrm{O}_{2}$ with concomitant generation of $\mathrm{O}_{2}{ }^{-}$, leaving a positively charged hole $\left(\mathrm{h}^{+}{ }_{\mathrm{VB}}\right)$ at the band edge of the VB. In addition to $\mathrm{O}_{2}{ }^{-}$, an adsorbed ${ }^{\circ} \mathrm{OH}$ may be formed on the oxide surface, from an $\mathrm{e}^{-}$abstracted by the $\mathrm{h}^{+}{ }_{\mathrm{VB}}$ hole from $\mathrm{H}_{2} \mathrm{O}$ or $\mathrm{OH}^{-}$(refs 15,36,40,42). Nonetheless, $\mathrm{O}_{2}$ may not be the only acceptor of the photogenerated single electrons, as ${ }^{1} \mathrm{O}_{2}$ also possesses sufficient one-electron reduction potential to form $\mathrm{O}_{2}{ }^{-}$(ref. 43). Then, the photogenerated $\mathrm{O}_{2}{ }^{-}$could be adsorbed on the surface of minerals where it could saturate their positively charged sites. In the long term, $\mathrm{O}_{2}{ }^{-}$may migrate via diffusive transport to greater depths in the soils, where it may stabilize as metal superoxides and peroxides (Table 1).

Metal superoxides/peroxides are better preserved (protected from dismutation/hydrolysis, respectively) in desiccated soils than in soils containing water ${ }^{42}$. This, in turn, depends on the clay mineral composition. Swelling clay minerals (smectite and vermiculite), that were more abundant in the control site soil, readily adsorb $\mathrm{H}_{2} \mathrm{O}$ molecules, thus contributing to greater water adsorption ${ }^{44}$ and possibly to lower stability of $\mathrm{O}_{2}{ }^{-}$and metal peroxides. This assumption could explain the observed 10-fold lower concentration of metal superoxides and the much lower concentration of metal peroxides in the control soil compared with the desert soils (Table 1).

Moreover, the presence of albite and labradorite plagioclase in the Atacama and Mojave Desert soils, respectively, is in agreement with the previously proposed ultraviolet-induced mechanism of $\mathrm{O}_{2}{ }^{-}$generation by these minerals ${ }^{17,42}$. The same mechanism might also apply for the albite-bearing control site soil. Also, metal superoxides and peroxides may be continuously photogenerated in all soils because $\mathrm{TiO}_{2}, \mathrm{Fe}-$ oxides and Fe-Ti-oxides-present in the tested soils and typical of desert soils ${ }^{45}$-are known to be involved in the photogeneration process of $\mathrm{O}_{2}^{-}$(refs 13-15,17,36). In addition to $\mathrm{Ti}$ (in $\mathrm{Ti}$ - and/or Fe-Ti-oxides) as well as $\mathrm{Fe}$ and $\mathrm{Mn}$ (in $\mathrm{Fe}$ and/or Mn-oxides either free or impurities in silicate minerals), the long-term stabilization process for adsorbed soil $\mathrm{O}_{2}{ }^{-}$as metal superoxides and peroxides also may involve (besides $\mathrm{Ti}^{46}$ ) the exchangeable metals $\mathrm{Ca}, \mathrm{Na}$ and $\mathrm{K}$ that are present in smectite. Specifically, $\mathrm{O}_{2}{ }^{-}$may be stabilized as (i) metal superoxides such as $\mathrm{KO}_{2}$ and $\mathrm{NaO}_{2}$, (ii) metal peroxides such as $\mathrm{Na}_{2} \mathrm{O}_{2}, \mathrm{CaO}_{2}, \mathrm{~K}_{2} \mathrm{O}_{2}$ and $\mathrm{TiO}_{3} \cdot 2 \mathrm{H}_{2} \mathrm{O}$ and $\mathrm{TiO}_{2} \cdot 2 \mathrm{H}_{2} \mathrm{O}$ (both less water soluble) that are usually formed by the reaction of the metal with $\mathrm{H}_{2} \mathrm{O}_{2}$ and (iii) metal hydroperoxides such as $\mathrm{NaOOH}$, $(\mathrm{KOOH})_{2} \cdot 3 \mathrm{H}_{2} \mathrm{O}$ and $\left.\mathrm{Ti}(\mathrm{OH})_{3} \mathrm{OOH}\right)^{27,28}$.

The photochemical production of $\mathrm{O}_{2}^{-}$as soil adsorbate and stabilized as metal superoxides/peroxides could explain the reactivity of desert soils with organics (Fig. 4) under several considerations. Soil $\mathrm{H}_{2} \mathrm{O}_{2}$ (for example, aqueously generated via reactions 1-4) can decompose carbohydrates to formic acid and ultimately to $\mathrm{CO}_{2}$ (ref. 47). The release of $\mathrm{NOy}$ from the Mojave Desert soil ${ }^{3}$ and $\mathrm{N}_{2} \mathrm{O}$ from the Atacama Desert soil ${ }^{48}$ ) could have resulted from ' $\mathrm{OH}$ by the following mechanism: ${ }^{\prime} \mathrm{OH}$ can oxidize amino acids with ammonia as a byproduct. Ammonia can be further oxidized by $\mathrm{OH}$ to amidogen radical $^{49}$, that can subsequently react with $\mathrm{O}_{2}$ to form nitric oxide radical ( ${ }^{\mathrm{NO}}$ ), dioxide radical ( $\mathrm{NO}_{2}$ ) and $\mathrm{N}_{2} \mathrm{O}$ (refs 49-51).

Hydroxyl radical can be generated from $\mathrm{H}_{2} \mathrm{O}_{2}$ (the product of dismutation/hydrolysis of metal superoxides/peroxides, respectively) either by the Fenton reaction (5) catalysed by $\mathrm{Me}_{\text {tr }}$ or by $\mathrm{O}_{2}^{-}$via the $\mathrm{Me}_{\mathrm{tr}}$-catalysed Haber-Weiss reaction (6) ${ }^{30}$ :

$$
\begin{gathered}
\mathrm{H}_{2} \mathrm{O}_{2}+\mathrm{Me}_{\mathrm{tr}}^{n} \rightarrow \mathrm{Me}_{\mathrm{tr}}^{n+1}+\mathrm{OH}^{-}+\mathrm{OH} \\
\mathrm{O}_{2}^{--}+\mathrm{H}_{2} \mathrm{O}_{2} \rightarrow \mathrm{OH}+\mathrm{OH}^{-}+\mathrm{O}_{2}
\end{gathered}
$$

The Fenton mechanism is considered probable because $\mathrm{Me}_{\mathrm{tr}}$ $\left(\mathrm{Fe}^{3+}\right.$ and trace elements $\mathrm{Cu}, \mathrm{Cr}, \mathrm{Co}$ and $\left.\mathrm{Ni}\right)$ were identified in Mojave and Atacama Desert soils (Tables 1 and 2). $\mathrm{Me}_{\text {tr }}$ might exist in the desert soils in their reduced and/or oxidized form and can participate in the Fenton reaction (5) with their reduced form directly. For example, $\mathrm{Fe}^{2+}$ might occur as interlayer species such as the $\mathrm{Fe}^{2+}$-aquo complex in the 2:1 clay minerals ${ }^{52}$. Also $\mathrm{Fe}^{3+}$ may participate in the Fenton reaction indirectly after its reduction by $\mathrm{H}_{2} \mathrm{O}_{2}$ (ref. 30) or $\mathrm{O}_{2}^{-}\left(\mathrm{O}_{2}^{-}+\mathrm{Me}_{\mathrm{tr}}^{n+1} \rightarrow\right.$ $\mathrm{Me}_{\mathrm{tr}}^{n}+\mathrm{O}_{2}$; the sum of this reaction with the Fenton reaction 5 is the $\mathrm{Me}_{\mathrm{tr}}$-catalysed Haber-Weiss reaction 6; ref. 12). Therefore, $\mathrm{Me}_{\text {tr }}$ can convert the weak oxidants $\mathrm{H}_{2} \mathrm{O}_{2}$ and $\mathrm{O}_{2}{ }^{-}$to the highly reactive $\mathrm{OH}$.

We showed that the instability of the Atacama and Mojave Desert soil metal superoxides/peroxides (as $\mathrm{H}_{2} \mathrm{PO}_{4}$-extracted $\mathrm{H}_{2} \mathrm{O}_{2}$ ) in the dark is associated with the production of $\mathrm{OH}$ (Fig. 1). The possible involvement of the Fenton reaction mechanism can be implied by the concurrence of the higher (threefold) production of $\mathrm{OH}$ in Atacama (Yungay site) over Mojave (+ CIMA site) with the higher concentration of $\mathrm{Me}_{\mathrm{tr}}$ (four and twofold higher in $\mathrm{Cu}$ and $\mathrm{Co}$ ), respectively (Table 2). $\mathrm{H}_{2} \mathrm{O}_{2}$ could be destabilized by other factors such as alkaline $\mathrm{pH}$ (via the hydrolysis reaction: $2 \mathrm{H}_{2} \mathrm{O}_{2} \rightarrow 2 \mathrm{H}_{2} \mathrm{O}+\mathrm{O}_{2}$; ref. 53). However, this is not a likely scenario given the stabilizing effect of phosphates and acidic $\mathrm{pH}$ on $\mathrm{H}_{2} \mathrm{O}_{2}$ (ref. 54), with the latter confirmed by the relative stability of a control $\mathrm{H}_{2} \mathrm{O}_{2}$ solution in $10 \mathrm{mM} \mathrm{H}_{3} \mathrm{PO}_{4}$ (Fig. 1a). Therefore, the identification of $\mathrm{OH}$ in the Atacama aqueous soil extracts (Fig. 1a) could explain the previous observation of the oxidation (to $\mathrm{CO}_{2}$ ) of sodium formate and aqueous mixtures of chiral sodium alanine and glucose after incubation for several days with Atacama Desert soil even in the dark, albeit at a slower rate ${ }^{1}$. The reactivity of the Atacama Desert soils with organics in the dark may not proceed by direct involvement of ${ }^{1} \mathrm{O}_{2}$, as its lack of charge would hinder its adsorption on the surface of soils. Moreover, non-light-induced abiotic oxidation of organics also may be involved in desert soils because the process has shown that Mn-oxides and Fe-oxides/ hydroxides common in desert soils (and in the tested ones, Table 2) could cause oxidation of organics (for example, 17betaestradiol $^{55}$ ) and aromatic amines ${ }^{56}$. Similarly, perchlorates 
(present in both Atacama and Mojave Deserts ${ }^{34,35}$ ) could be potential oxidants of soil organics ${ }^{57-59}$.

The oxidation of soil organics by photogenerated ROS may be a continuous process given that $\mathrm{Me}_{\mathrm{tr}}$ are ubiquitous in all soils. $\mathrm{O}_{2}{ }^{-}$may represent a fraction of the ROS produced in photoirradiated desert soils, however. Another ROS could be ${ }^{1} \mathrm{O}_{2}$ because it is generated-and oxidizes organics-by photoirradiated minerals such as $\mathrm{MgO}, \mathrm{Al}_{2} \mathrm{O}_{3}$ and $\mathrm{SiO}_{2}$ (refs $18,19,60)$, which are common in desert soils and also found in the tested soils (Table 2). Moreover, ${ }^{1} \mathrm{O}_{2}$ could be formed directly by reaction of $\mathrm{O}_{2}{ }^{-}$with $\mathrm{H}_{2} \mathrm{O}_{2}$ (refs 61,62 ), and possibly by the decomposition of light-generated $\mathrm{O}_{2}{ }^{-}$on irradiated surface soils ${ }^{18}$. In addition, ${ }^{1} \mathrm{O}_{2}$ can form $\mathrm{O}_{2}{ }^{-}$because it possesses the required one-electron reduction potential $(+0.65 \mathrm{~V}$ at $\mathrm{pH} 7.0)$, while its two-electron reduction could generate $\mathrm{H}_{2} \mathrm{O}_{2}$ (ref. 43). Therefore, photogeneration of $\mathrm{O}_{2}^{-}$from ${ }^{1} \mathrm{O}_{2}$ could have been possible under non-aqueous conditions as long as it involves a highly reactive single electron photo-ejected from soil minerals or donated by soil organic photosensitizers.

The present study also showed that $\mathrm{O}_{2}{ }^{-}$is photogenerated by desert soils (Fig. 2a). $\mathrm{O}_{2}^{-}$is generated at similar levels even by soils prewashed before exposure from polar inorganic and polar/ non-polar organic soil constituents, suggesting a mechanism not involving photosensitization and the involvement of perchlorates. These prewashed soils also photogenerated ${ }^{\circ} \mathrm{OH}$ under aqueous conditions (Fig. 3) and at a near 1:1 molar rate ratio with the $\mathrm{O}_{2}{ }^{-}$that is generated (in the 1st hour) by sunlight-exposed desiccated soils (Fig. 2a), in agreement with the mechanism for $\mathrm{TiO}_{2}$ photocatalysis ${ }^{15,36}$. The same mechanism also could apply for the desert soils (Fig. 4) since they contain transition metal oxides such as $\mathrm{TiO}_{2}$ and Fe-Ti-oxides (Table 2). Moreover, the photo-catalytic generation of $\mathrm{OH}$ by aqueous desert soils could provide a light-based mechanism for their reactivity with organics. This would involve the photo-catalytic ejection of an electron from metal oxides (to generate $\mathrm{O}_{2}{ }^{-}$by dissolved $\mathrm{O}_{2}$ ) and the subsequent abstraction of an electron by the resulting $\mathrm{h}^{+}{ }_{\mathrm{vB}}$ hole from $\mathrm{H}_{2} \mathrm{O}$ or $\mathrm{OH}^{-}$(resulting also from $\mathrm{H}_{2} \mathrm{O}$ via reaction with a bridging-oxygen atom ${ }^{15}$ ). Then, $\mathrm{OH}$ (and $\mathrm{H}_{2} \mathrm{O}_{2}$ to a lesser degree) could oxidize soil organics to $\mathrm{CO}_{2}$ and $\mathrm{NOy}$.

The photogenerated ROS detected in desert soils also may explain the ionizing radiation resistance of certain desert bacteria-notably Deinococcus radiodurans and Chroccocidiopsis -that can withstand extraordinarily high levels of ionizing radiation $^{63}$. Radiation resistance is regarded as a proxy for desiccation resistance ${ }^{63}$. Ionizing radiation also produces reactive oxidants similar to photochemical oxidants ${ }^{64}$. Thus, the ability to withstand photochemical oxidants might explain the resistance of desert bacteria to radiation.

Finally, an extreme example of this soil oxidant chemistry appears to take place on Mars. The oxidative reactivity of the Martian soil as measured by the Viking Biology Experiments (and exhibited on the organics of a certain nutrient by releasing $\mathrm{O}_{2}$ and $\mathrm{CO}_{2}$ (refs 65,66)), requires a mix of oxidants in the soil including oxidants capable of destroying organics ${ }^{57,67}$. Production of $\mathrm{O}_{2}{ }^{-}$ by the photo-induced transition metal oxide surface- $\mathrm{O}_{2}$ electron transfer mechanism has been suggested ${ }^{17}$. Other alternative potential pathways may involve (i) photogeneration of ROS on mineral substrates (for example, plagioclase) that can generate $\mathrm{O}_{2}{ }^{-}$from adsorbed $\mathrm{O}_{2}$ on $\mathrm{TiO}_{2}$ and (ii) photoactive on Mars Fe-oxides such as hematite being analogous to $\mathrm{TiO}_{2}$ in surface catalysis $^{42}$. The source of $\mathrm{O}_{2}$ needed for the photogeneration of $\mathrm{O}_{2}{ }^{-}$in Martian topsoil under an $\mathrm{O}_{2}$-depleted atmosphere, however, has not been elucidated. It could be that $\mathrm{O}_{2}$ might have been released by perchlorate (given its abundance on Mars ${ }^{68,69}$ ) on exposure to cosmic radiation. This is supported by the generation of $\mathrm{O}_{2}$ by perchlorate exposed to gamma rays in a $\mathrm{CO}_{2}$ atmosphere $^{57}$. Nonetheless, the buildup of soil ROS oxidants on Mars would be less impeded by liquid water than even the driest desert on Earth.

Accumulated metal superoxides and peroxides were detected in soils from the Atacama (hyper-arid) and Mojave (arid) deserts. Moreover, desiccated desert soils photogenerate $\mathrm{O}_{2}^{-}$at saturation levels, followed by long-term stabilization by diffusion as soil metal superoxides and peroxides. Desert soils photogenerate $\mathrm{OH}$ under aqueous conditions. The photogeneration of $\mathrm{O}_{2}^{-}$by desiccated or aqueous soils may proceed via capture by $\mathrm{O}_{2}$ of a single electron that is photo-ejected from metal oxides (for example, $\mathrm{TiO}_{2} / \mathrm{Fe}_{2} \mathrm{O}_{3}$ detected in the tested soils). The resulting $\mathrm{h}^{+}{ }_{\mathrm{VB}}$ hole in $\mathrm{H}_{2} \mathrm{O}$-wetted soil metal oxides can, then, abstract a single electron from $\mathrm{H}_{2} \mathrm{O}$ or $\mathrm{OH}^{-}$and generate $\mathrm{OH}$. Moreover, aqueous desert soil metal superoxides/peroxides are converted (by dismutation/hydrolysis, respectively) to $\mathrm{H}_{2} \mathrm{O}_{2}$, the observed instability of which in the dark concurs with the generation of $\cdot \mathrm{OH}$, possibly via the Fenton reaction due to the presence in these soils of $\mathrm{Me}_{\mathrm{tr}}$. The generation of $\mathrm{OH}$, in the dark (via the Fenton reaction) and by photocatalysis could explain the abiotic oxidation of organics by desert soils, with $\mathrm{H}_{2} \mathrm{O}_{2}$ and $\mathrm{O}_{2}^{-}{ }^{-}$acting as weak oxidants. Similar ultraviolet-induced processes may take place in the topsoils of Mars.

\section{Methods}

Samples and reagents. Full details of sample collection and treatment are available in the Supplementary Methods section, with details of the reagents used.

HE-based soil $\mathbf{O}_{\mathbf{2}}^{-}$assay. Assay principle and other supporting control experiments are described in full in the Supplementary Methods.

Reagent solutions. $100 \%$ alkaline acetonitrile. It is made by mixing $100 \%$ acetonitrile (ACN) with $0.1 \mathrm{M} \mathrm{NaOH}$ at a 100:1 ratio. At this $\mathrm{NaOH}$ proportion (it mixes almost completely as it leaves a small aqueous droplet in the bottom of the tube, resulting in $\sim 99 \% \mathrm{ACN}$ ) and higher, the resulting $\mathrm{ACN}_{\text {alk }}$ solvent is saturated with hydroxyl ions, reaching a stable $\mathrm{pH} 8-8.5$. For the $\mathrm{pH}$ measurements a Sentron Argus-type $\mathrm{pH}$ Meter was used, equipped with a non-glass Hot-Line electrode (Sentron, The Netherlands).

$100 \mathrm{mM} \mathrm{CE}$. It is prepared by dissolving $186 \mathrm{mg}$ dicyclohexano-18-crown-6 ether (CE) in $5 \mathrm{ml} \mathrm{ACN}_{\mathrm{alk}}$. Prepare fresh, keep at $4{ }^{\circ} \mathrm{C}$. Caution: accurate pipetting of the reagent is required.

Soil $\mathrm{O}_{2}^{-}{ }^{-} A C N_{\text {alk }}-C E$ extraction solutions. Solution $\mathrm{ACN}_{\mathrm{alk}}-\mathrm{CE}(0.2 \mathrm{mM})$ is prepared by mixing $29.94 \mathrm{ml} \mathrm{ACN}$ alk with $60 \mu \mathrm{l} 100 \mathrm{mM} \mathrm{CE}$. This standard solution is designated also as $\mathrm{ACN}_{\text {alk }}$-CE. $\mathrm{ACN}_{\text {alk }}$ solutions containing other $\mathrm{CE}$ concentrations can be prepared from the $100 \% \mathrm{ACN}_{\text {alk }}$ and $100 \mathrm{mM} \mathrm{CE}$ stocks. For example, $\mathrm{ACN}_{\text {alk }}-\mathrm{CE}(1 \mathrm{mM})$ solution is made by mixing $29.7 \mathrm{ml} \mathrm{ACN}_{\text {alk }}$ with $0.3 \mathrm{ml} 100 \mathrm{mM}$ CE. The $\mathrm{ACN}_{\mathrm{alk}}-\mathrm{CE}$ extraction solutions should be prepared fresh, and kept in an airtight and light-protected glass container at $4{ }^{\circ} \mathrm{C}$.

$0.5 \mathrm{mM} \mathrm{HE}$. Prepare fresh (and kept at $4{ }^{\circ} \mathrm{C}$, protected from light) by dissolving $1.2 \mathrm{mg} \mathrm{HE}$ in $7.5 \mathrm{ml} \mathrm{ACN} \mathrm{alk}-\mathrm{CE}(0.2 \mathrm{mM})$ solution. Caution: accurate pipetting of the reagent is required.

$50 \mathrm{mM} \mathrm{HCl}$. Prepare by diluting $\times 240$ (with $\mathrm{ddH}_{2} \mathrm{O}$ ) the concentrated $37 \%$ $\mathrm{HCl}$ (or $12 \mathrm{M}$ ). Caution: accurate pipetting of thr reagent is required.

$1 M$ Tris-base, $p H$ 8.0. Caution: accurate pipetting of the reagent is required.

Protocol. Soil samples were treated as follows: $1 \mathrm{~g}$ soil is placed in a $15-\mathrm{ml}$ plastic centrifuge tube (with conical bottom) with $2.5 \mathrm{ml} \mathrm{ACN}$ alk or $\mathrm{ACN}_{\mathrm{alk}}-\mathrm{CE}$ (for example, $0.2 \mathrm{mM}$ ) and mixed by shaking for $2-3 \mathrm{~min}$ at room temperature (RT; to extract $\mathrm{O}_{2}^{-}$), and the soil is removed by precipitation (or filtration). The supernatants are diluted appropriately with $\mathrm{ACN}_{\text {alk }}-\mathrm{CE}$ to set the $\mathrm{CE}$ concentration in the $\mathrm{ACN}_{\text {alk }}$ extract to final $0.2 \mathrm{mM}$ and are kept capped in an ice-water bucket.

NOTES: I. Soil metal superoxides can be extracted effectively by an $\mathrm{ACN}_{\text {alk }}-\mathrm{CE}$ solution. Testing various concentrations of CE (for example, $0.2,1 \mathrm{mM}$ ) in the $\mathrm{ACN}_{\mathrm{alk}}$ extraction solution allows the determination of the optimum $\mathrm{CE}$ concentration for solubilizing the maximum quantity of soil metal salts of $\mathrm{O}_{2}-$ This can be tested by extracting soil $\mathrm{O}_{2}{ }^{-}$with $\mathrm{ACN}_{\text {alk }}$ mixed with various $\mathrm{CE}$ concentrations, to determine a minimum $\mathrm{CE}$ concentration above which the extracted $\mathrm{O}_{2}{ }^{-} \mathrm{g}^{-1}$ soil is constant. II. For extracting soil-adsorbed $\mathrm{O}_{2}^{-}$the $\mathrm{ACN}_{\text {alk }}$ extraction solution does not need the presence of CE and the $\mathrm{ACN}_{\mathrm{alk}}$ solution can be used alone. However, $\mathrm{ACN}_{\text {alk }}$ may also extract soil metal superoxides although not as effectively as being in mixture with CE.

The $\mathrm{ACN}_{\text {alk }}-\mathrm{CE}$ supernatants from the preceeding step are split in two halves (in two $1.5-\mathrm{ml}$ microcentrifuge tubes), one designated 'sample' (S) and the other 
'blank' (B), which are centrifuged at $12,000 \mathrm{~g}$ for $3 \mathrm{~min}$ at RT to remove any soil remnants. Then, $880 \mu \mathrm{l}$ clear supernatant from each half tube are transferred in new tubes to each of which $80 \mu \mathrm{l} 0.5 \mathrm{mM} \mathrm{HE}$ are added $(40 \mu \mathrm{M}$ final in the assay).

NOTES: I. For this step, sample/blank tubes are kept in an ice-water bath. II. If using quartz micro-cuvette holding a sample volume $0.3-0.5 \mathrm{ml}$, (cuvette dimensions $45 \times 4 \times 4, \mathrm{~mm}$ with the Shimadzu RF-1501 spectrofluorometer), the total sample volume required can be minimized to $\sim 1 \mathrm{ml}(0.45 \mathrm{ml}$ per $\mathrm{S}$ and $\mathrm{B})$, which results in halving the volumes of the reagents added in this and in the subsequent two steps.

Thereafter, the following alternative Procedures A and B can be followed:

Procedure A: to the B and S tubes, $20 \mu \mathrm{l} 50 \mathrm{mM} \mathrm{CE}$ and $20 \mu \mathrm{l} \mathrm{ACN} \mathrm{alk}^{-} \mathrm{CE}$ $(0.2 \mathrm{mM})$ are added, respectively, followed by the addition in both tubes of $20 \mu \mathrm{l}$ $50 \mathrm{mM} \mathrm{HCl}\left(1 \mathrm{mM} \mathrm{H}^{+}\right.$concentration in the final assay mixture) and mixing by inversion up to $1 \mathrm{~min}$. For preparing the assay reagent blanks, in each of the two microcentrifuge tubes $880 \mu \mathrm{l} \mathrm{ACN} \mathrm{alk}_{\mathrm{k}}-\mathrm{CE}(0.2 \mathrm{mM})$ and $80 \mu \mathrm{l} 0.5 \mathrm{mM} \mathrm{HE}$ are added, followed by the addition in one tube of $20 \mu \mathrm{l} 50 \mathrm{mM} \mathrm{CE}$ and $20 \mu \mathrm{l} 50 \mathrm{mM} \mathrm{HCl}$ (designated $\mathrm{R}_{\mathrm{CE}-1 \mathrm{mM}}$ ) and in the other tube of $20 \mu \mathrm{ACN}_{\mathrm{alk}^{-}} \mathrm{CE}(0.2 \mathrm{mM})$ and $20 \mu \mathrm{l}$ $50 \mathrm{mM} \mathrm{HCl}$ (designated $\mathrm{R}_{\mathrm{CE}-0.2 \mathrm{mM}}$ ).

NOTES: I. In the $\mathrm{S}$ tube, $\mathrm{HE}$ reacts with $\mathrm{O}_{2}{ }^{-}$(the reaction requires at least $\left.0.5 \mathrm{mM} \mathrm{H}^{+}\right)$and forms the fluorescent product 2-hydroxy ethidium $\left(2-\mathrm{OH}-\mathrm{E}^{+}\right.$; at molar stoichiometric ratio $\mathrm{O}_{2}{ }^{-} / 2-\mathrm{OH}-\mathrm{E}^{+}=2 / 1$ ) at $0.2 \mathrm{mM} \mathrm{CE}$, while in the $\mathrm{B}$ tube, this reaction is inhibited by the inclusion of $1 \mathrm{mM}$ CE. II. For the reaction of $\mathrm{HE}$ with $\mathrm{O}_{2}^{-}$in $1 \mathrm{mM} \mathrm{HCl}$ to take place, the $\mathrm{pH}$ of the assay mixture must be acidic ( $\mathrm{pH} 1.5-2)$. Possible alkalinity of soil may change this $\mathrm{pH}$, therefore, a test of the assay mixture $\mathrm{pH}$ must be performed and if needed the final concentration of $\mathrm{HCl}$ can be adjusted appropriately to bring the assay $\mathrm{pH}$ to $1.5-2$. III. This step and the subsequent two steps are performed as soon as possible to minimize the possible oxidation of HE by any extracted soil constituents.

After the 1-min incubation period, the assay mixtures in the $S, B, R_{C E-1 ~ m M}$ and $\mathrm{R}_{\mathrm{CE}-0.2 \mathrm{mM}}$ tubes are mixed with $10 \mu \mathrm{l} 1 \mathrm{M}$ Tris by brief vortexing (to adjust the assay mixture $\mathrm{pH}$ to $\sim 8$ ), centrifuged at $12,000 \mathrm{~g}$ for $1 \mathrm{~min}$ and the resulting supernatants are collected for fluorescence measurement.

The fluorescence units (FUs) of the $\mathrm{S}, \mathrm{B}, \mathrm{R}_{\mathrm{CE}-0.2 \mathrm{mM}}$ and $\mathrm{R}_{\mathrm{CE}-1 \mathrm{mM}}$ supernatants are measured at ex/em 505/580 $\mathrm{nm}$ (designated $\mathrm{FU}_{\mathrm{S}}, \mathrm{FU}_{\mathrm{B}}, \mathrm{FU}_{\mathrm{RCE}-0.2 \mathrm{mM}}$ and $\mathrm{FU}_{\mathrm{RCE}-1 \mathrm{mM}}$, respectively). From these FU, the net FU of $2-\mathrm{OH}-\mathrm{E}^{+}$is calculated from the following formula: net $\mathrm{FU}_{2-\mathrm{OH}-\mathrm{E}^{+}}=\mathrm{FU}_{S}-\mathrm{FU}_{B}-\left(\mathrm{FU}_{R C E}-0.2 \mathrm{mM}-\right.$

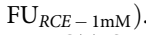

NOTES: I. To verify that the net $\mathrm{FU}_{2-\mathrm{OH}-\mathrm{E}^{+}}$corresponds to the concentration of the extracted $\mathrm{O}_{2}{ }^{-}$, various dilutions of the $\mathrm{ACN}_{\text {alk }}{ }^{-} \mathrm{CE}$ supernatants (derived in the first two steps of the Assay Protocol) should be tested (as in this and the previous two steps in Procedure A) and only those dilutions resulting in proportional $\mathrm{FU}_{2-\mathrm{OH}-\mathrm{E}^{+}}$values will be used for determining the final average $\mathrm{FU}_{2-\mathrm{OH}-\mathrm{E}}+$ value. II. The $\mathrm{FU}_{\mathrm{RCE}-0.2 \mathrm{mM}}$ and $\mathrm{FU} \mathrm{RCE}_{\mathrm{R} 1 \mathrm{mM}}$ values can be kept as low as possible by setting the HE final concentration in the assay (see second step in the Assay Protocol) at low levels (for example, $20-40 \mu \mathrm{M} \mathrm{HE}$ ), given that $\mathrm{O}_{2}{ }^{-}$is quite stable in the $\mathrm{ACN}_{\mathrm{alk}}$ extraction solvent. The $\mathrm{FU} \mathrm{RCE}_{\mathrm{R}-0.2 \mathrm{mM}}-\mathrm{FU}_{\mathrm{RCE}-1 \mathrm{mM}}$ value is in the order of $50 \mathrm{FU}$. Much higher values suggest an excessive autoxidation of HE, and a fresh HE stock solution (see Assay Reagent Solutions) should be used. III. In case $\mathrm{FU}_{\mathrm{S}}<\mathrm{FU}_{\mathrm{B}}$, the soil extract may contain a soil constituent, which in the presence of $1 \mathrm{mM} \mathrm{CE}$ (in tube $\mathrm{B}$ ) oxidizes $\mathrm{HE}$ to $\mathrm{E}^{+}$. In this case, the alternative Procedure B is followed.

Procedure B: to the B and S tubes, 40 and $20 \mu \mathrm{ACN} \mathrm{Allk}-\mathrm{CE}(0.2 \mathrm{mM})$ are added, respectively, followed by the addition in the $\mathrm{S}$ tube of $20 \mu \mathrm{l} 50 \mathrm{mM} \mathrm{HCl}\left(1 \mathrm{mM} \mathrm{H}^{+}\right.$ concentration in the final assay mixture) and mixing by inversion up to $1 \mathrm{~min}$. For preparing the assay reagent blanks, in each of the two microcentrifuge tubes $880 \mu \mathrm{l} \mathrm{ACN}$ alk $^{-} \mathrm{CE}(0.2 \mathrm{mM})$ and $80 \mu \mathrm{l} 0.5 \mathrm{mM} \mathrm{HE}$ are added, followed by the addition in one tube of $20 \mu \mathrm{l} \mathrm{ACN}$ alk $-\mathrm{CE}(0.2 \mathrm{mM})$ and $20 \mu \mathrm{l} 50 \mathrm{mM} \mathrm{HCl}$ (designated $\mathrm{R}_{\mathrm{HCl}-1 \mathrm{mM}}$ ) and in the other tube of $40 \mu \mathrm{l} \mathrm{ACN} \mathrm{alk}-\mathrm{CE}(0.2 \mathrm{mM})$ (designated $\mathrm{R}_{\mathrm{HCl}-\mathrm{OmM}}$ ).

NOTES: I. In the $\mathrm{S}$ tube, $\mathrm{HE}$ reacts with $\mathrm{O}_{2}{ }^{-}$(the reaction requires at least $0.5 \mathrm{mM} \mathrm{H}^{+}$) and forms the fluorescent product $2-\mathrm{OH}-\mathrm{E}^{+}$(at $0.2 \mathrm{mM} \mathrm{CE}$ ), while in the $\mathrm{B}$ tube, this reaction does not take place (also in the presence of $0.2 \mathrm{mM} \mathrm{CE}$ ) because $\mathrm{HCl}$ is absent. II. For the reaction of $\mathrm{HE}$ with $\mathrm{O}_{2}{ }^{-}$in $1 \mathrm{mM} \mathrm{HCl}$ to take place, the $\mathrm{pH}$ of the assay mixture must be acidic ( $\mathrm{pH} 1.5-2)$. Possible alkalinity of soil may change this $\mathrm{pH}$, therefore, a test of the assay mixture $\mathrm{pH}$ must be performed, and if needed the final concentration of $\mathrm{HCl}$ can be adjusted appropriately to bring the assay $\mathrm{pH}$ to $1.5-2$. III. This step and the subsequent two steps are performed as soon as possible to minimize the possible oxidation of HE by any co-extracted soil constituents.

After the 1-min incubation period, the assay mixtures in the $\mathrm{S}, \mathrm{B}, \mathrm{R}_{\mathrm{HCl}-1 \mathrm{mM}}$ and $\mathrm{R}_{\mathrm{HCl}-0 \mathrm{mM}}$ tubes are mixed with $10 \mu \mathrm{l} 1 \mathrm{M}$ Tris by brief vortexing (to adjust the assay mixture $\mathrm{pH}$ to $7-8$ ), centrifuged at $12,000 \mathrm{~g}$ for $1 \mathrm{~min}$ and the resulting supernatants are collected for fluorescence measurement.

The FU of the $\mathrm{S}, \mathrm{B}, \mathrm{R}_{\mathrm{HCl}-\mathrm{omM}}$ and $\mathrm{R}_{\mathrm{HCl}-1 \mathrm{mM}}$ supernatants are measured at ex/em 505/580 nm (designated $\mathrm{FU}_{\mathrm{S}}, \mathrm{FU}_{\mathrm{B}}, \mathrm{FU}_{\mathrm{RHCl}-0 \mathrm{mM}}$ and $\mathrm{FU}_{\mathrm{RHCl}-1 \mathrm{mM}}$ respectively). From these $\mathrm{FU}$, the net $\mathrm{FU}$ of $2-\mathrm{OH}-\mathrm{E}^{+}$is calculated from the following formula: net $\mathrm{FU}_{2-\mathrm{OH}_{-} \mathrm{E}^{+}}=\mathrm{FU}_{\mathrm{S}}-\mathrm{FU}_{B^{-}}\left(\mathrm{FU}_{R} \mathrm{HCl}-1 \mathrm{mM}-\mathrm{FU}_{R} \mathrm{HCl}-0 \mathrm{mM}\right)$.

NOTES: I. To verify that net $\mathrm{FU}_{2-\mathrm{OH}-\mathrm{E}^{+}}$corresponds to the concentration of the extracted $\mathrm{O}_{2}{ }^{-}$, various dilutions of the $\mathrm{ACN}_{\text {alk }}{ }^{-} \mathrm{CE}$ supernatants (derived as in the first two steps of the Assay Protocol) should be tested (as in this and the previous two steps in Procedure B) and only those dilutions resulting in proportional $\mathrm{FU}_{2-\mathrm{OH}-\mathrm{E}^{+}}$values will be used for determining the final average $\mathrm{FU}_{2-\mathrm{OH}-\mathrm{E}^{+}}$value. II. The $F U_{\text {RCE- } 02 \mathrm{mM}}$ and $\mathrm{FU}_{\mathrm{RCE}-1 \mathrm{mM}}$ values can be kept as low as possible by setting the HE final concentration in the assay (see second step in the Assay Protocol) at low levels (for example, $20-40 \mu \mathrm{M} \mathrm{HE}$ ). The $\mathrm{FU}_{\mathrm{RHCl}-1 \mathrm{mM}}-\mathrm{FU}_{\mathrm{RHCl}}$ $0 \mathrm{mM}$ value should be in the order of $100 \mathrm{FU}$. Much higher values suggest an excessive autoxidation of HE, and a fresh HE stock solution (see Assay Reagent Solutions) should be used.

To convert the net $\mathrm{FU}_{2-\mathrm{OH}-\mathrm{E}^{+}}$value to the concentration of $2-\mathrm{OH}-\mathrm{E}^{+}$ (and subsequently of $\mathrm{O}_{2}^{-}$) in the assay mixture volume ( $1 \mathrm{ml}$, in this case), the spectrofluorometer in use must be calibrated with known concentrations of $2-\mathrm{OH}-\mathrm{E}^{+}$by determining the fluorescence extinction coefficient of $2-\mathrm{OH}-\mathrm{E}^{+}$ ( $\mathrm{FEC}_{2-\mathrm{OH}-\mathrm{E}}^{+}$, expressed in $\mathrm{FU}$ per $1 \mu \mathrm{M}^{-1} 2-\mathrm{OH}-\mathrm{E}^{+}$) as follows.

The $\mathrm{FEC}_{2-\mathrm{OH}-\mathrm{E}}^{+}$is determined in final $97 \% \mathrm{ACN}$ (same as the ACN final concentration in the assay reaction mixture) for the spectrofluorometer (set at high sensitivity) and quartz cuvette in use in this study, as follows: from a synthetic 2-OH-E ${ }^{+}$stock solution (see Supplementary Methods) of known concentration, $1 \mu \mathrm{M} 2-\mathrm{OH}-\mathrm{E}$ in $1 \mathrm{ml} \mathrm{ACN}$ alk (or $1 \mathrm{ml} \mathrm{ACN} \mathrm{alk}$-CE extraction solution) is prepared

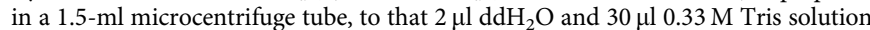
are added, and vortexed, and centrifuged at $12,000 \mathrm{~g}$ for $1 \mathrm{~min}$. Similarly is treated a reagent blank, which is prepared with $1 \mathrm{ml} \mathrm{ACN}$ alk (or $1 \mathrm{ml} \mathrm{ACN}$ alk-CE extraction

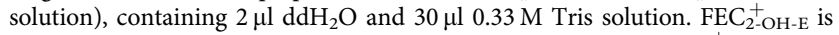
determined by measuring the $\mathrm{FU}$ value of the clear $1 \mu \mathrm{M} 2-\mathrm{OH}-\mathrm{E}^{+}$supernatant (at ex/em 505/580 nm) and subtracting from this value the $\mathrm{FU}$ of the clear supernatant of the blank.

Having determined $\mathrm{FEC}_{2-\mathrm{OH}-\mathrm{E}^{+}}$in the preceeding step, and given the molar stoichiometric ratio $\mathrm{O}_{2}{ }^{-} / 2-\mathrm{OH}-\mathrm{E}^{+}=2 / 1$, the netFU $\mathrm{F}_{2-\mathrm{OH}-\mathrm{E}^{+}}$(determined three steps before) is converted to a $\mu \mathrm{M}$ concentration of $2-\mathrm{OH}-\mathrm{E}^{+}$(in the assay mixture volume) and then to $\mu \mathrm{M} \mathrm{O}_{2}{ }^{-}$by the formula (see derivation in Supplementary Methods):

$$
\begin{aligned}
\mathrm{O}_{2}^{-}(\mu \mathrm{M}) & =2 \times\left[2-\mathrm{OH}-\mathrm{E}^{+}(\text {in } \mu \mathrm{M})\right]=2 \times\left(\mathrm{FU}_{2-\mathrm{OH}-\mathrm{E}+} / \mathrm{FEC}_{\text {ex } / \mathrm{em} 505 / 580 \mathrm{~nm}}\right) \\
& =2 \times \mathrm{FU} / 1300
\end{aligned}
$$

Finally, the $\mu \mathrm{M} \mathrm{O}_{2}{ }^{-}$(extracted from a known soil quantity) are converted to nmoles $\mathrm{O}_{2}{ }^{-} \mathrm{g}^{-1}$ soil.

Assay sensitivity. Applying the protocol on $1 \mathrm{~g}$ soil, extracted in $1 \mathrm{ml} \mathrm{ACN}_{\text {alk }}-\mathrm{CE}$ solution by filtration (to recover a $\sim 1.0 \mathrm{ml} \mathrm{ACN}_{\text {alk }}$-CE extract), with an assay reaction volume $0.5 \mathrm{ml}$ (containing $0.44 \mathrm{ml} \mathrm{ACN}$ alk $^{-} \mathrm{CE}$ extract) and a minimum net $\mathrm{FU}_{2-\mathrm{OH}-\mathrm{E}^{+}}=200$, the theoretical assay sensitivity (using the above formula) is $=200 \times 2 / 1300=\sim 0.3 \mu \mathrm{M} \mathrm{O}_{2}{ }^{-}$(in the assay reaction mixture, or 0.34 nmoles in $1.0 \mathrm{ml} \mathrm{ACN}_{\text {alk }}-\mathrm{CE}$ extract, or 0.34 nmoles $^{-1}$ soil).

SOD-inhibited reduction of cyt. c-based soil $\mathbf{O}_{\mathbf{2}}^{-}$assay. Protocol. Soil samples were mixed with a minimum $0.3 \mathrm{ml} \mathrm{O}_{2}$-degassed $\mathrm{ACN}_{\mathrm{alk}}$-CE $(0.2 \mathrm{mM})$ per gram of soil by shaking for $2-3 \mathrm{~min}$ at RT. This proportion achieves the maximum concentration of $\mathrm{O}_{2}{ }^{-}$extracted in a minimum solvent volume. Then, $\sim 0.5 \mathrm{~g}$ batches of this soil/ $\mathrm{ACN}_{\text {alk }}$-CE slurry were placed in centrifuge tube filters fitted to a 1.5-ml microcentrifuge collection tube, centrifuged at $15,000 \mathrm{~g}$ for $5 \mathrm{~min}$ and the $\mathrm{O}_{2}^{-}{ }^{-} / \mathrm{ACN}_{\mathrm{alk}^{-}}-\mathrm{CE}$ eluents of all the batches were combined and used in the following step.

NOTE: In this step and in subsequent steps, all the reagents used should be $\mathrm{O}_{2-}$ degassed as in two steps before.

Having established the molar stoichiometric ratio $1: 1$ of $\mathrm{O}_{2}{ }^{-}$to cyt. $c_{\text {red }}$ up to a final $40 \% \mathrm{ACN}_{\text {alk }}-\mathrm{CE}$ (see Supplementary Methods), the maximum $\mathrm{ACN}_{\text {alk }}-\mathrm{CE}$ solvent volume for the recovery of $\mathrm{O}_{2}{ }^{-}$from any soil sample is $0.4 \mathrm{ml}$. This volume is sufficient for the control if $\sim 0.5$-volume capacity cuvettes are used. Given that the minimum proportion of $\mathrm{ACN}_{\text {alk }}-\mathrm{CE}$ extraction volume/soil weight is $\sim 0.3 \mathrm{ml}$ per $1 \mathrm{~g}$, the maximum amount of soil that this assay can extract for measuring accurately the concentration of $\mathrm{O}_{2}{ }^{-}$in a $0.4 \mathrm{ml}$ extract is $1.3 \mathrm{~g}$. Therefore, $1.3 \mathrm{~g}$ soil samples were used extracted in $0.4 \mathrm{ml} \mathrm{ACN} \mathrm{alk}^{-} \mathrm{CE}$, and were diluted with $100 \% \mathrm{ACN}_{\text {alk }}$ - $\mathrm{CE}$ to $0.8 \mathrm{ml}$ (unless a smaller than 1 -ml spectrophotometer cuvette is used). A $0.4 \mathrm{ml}$ portion of the clear $\mathrm{ACN}_{\text {alk }}-\mathrm{CE}-\mathrm{O}_{2}-$ extract (after centrifugation at at $15,000 \mathrm{~g}$ for $5 \mathrm{~min}$ ) was mixed with $0.6 \mathrm{ml} 50 \mathrm{mM}$ phosphate buffer, $\mathrm{pH} 7.8$, containing $26.7 \mu \mathrm{M}$ cyt. $c_{\mathrm{ox}}$ (final $16 \mu \mathrm{M}$ ). Its absorbance was measured at $550 \mathrm{~nm}$ against a reagent blank $(0.4 \mathrm{ml} \mathrm{ACN}$ alk -CE plus $0.6 \mathrm{ml}$ $50 \mathrm{mM}$ phosphate buffer, $\mathrm{pH}$ 7.8) and also against the following SOD blank: It consists of the remaining $0.4-\mathrm{ml}$ portion of the $\mathrm{ACN}_{\text {alk }} \mathrm{CE}$ extract, mixed with $0.6 \mathrm{ml} 50 \mathrm{mM}$ phosphate buffer, $\mathrm{pH} 7.8$, containing $26.7 \mu \mathrm{M}$ cyt. $c_{\mathrm{ox}}$ and 3.3 units SOD (or SOD added before the addition of cyt. $c_{\mathrm{ox}}$ ). If $\mathrm{O}_{2}{ }^{-}$is present in the $0.4 \mathrm{ml}$ $\mathrm{ACN}_{\text {alk }}-\mathrm{CE}$ extract the assay will identify it from the SOD-inhibited reduction of cyt. $c_{\mathrm{ox}}$. Competing with cyt. $c_{\mathrm{ox}}$, SOD will reduce or eliminate the concentration of $\mathrm{O}_{2}{ }^{-}$by dismutation. This blank also quantifies possible soil contaminants that may cause chemical reduction of cyt. $c_{\mathrm{ox}}$ and/or absorb at $550 \mathrm{~nm}$. Then, the $\Delta A_{550 \mathrm{~nm}}$ (absorbance of the sample minus absorbance of the SOD blank) is converted nmoles of cyt. $c_{\text {red }}$, which correspond to equimolar $\mathrm{O}_{2}{ }^{-}$derived from the standard curve of cyt. $c_{\text {red }}$ versus $\mathrm{O}_{2}{ }^{-}$concentration (see Supplementary Methods). The sensitivity of the assay is $\sim 0.5 \mathrm{nmoles}_{2} \mathrm{O}^{-}$(or $0.5 \mu \mathrm{M}$ in the $\mathrm{ACN}_{\text {alk }}-\mathrm{CE} /$ phosphate buffer assay mixture). 
NOTE: The $0.4 \mathrm{ml}$ of the $\mathrm{ACN}_{\text {alk }}-\mathrm{CE}_{-} \mathrm{O}_{2}{ }^{-}$soil extract should be rapidly mixed with the 0.6-ml phosphate-buffered cyt. $c_{\mathrm{ox}}$ in the spectrophotometer cuvette and its peak absorbance immediately measured as it rapidly decreases due to the reoxidation of cyt. $c_{\text {red }}$.

Assay for soil total metal superoxides/peroxides and $\mathrm{Fe}^{\mathbf{3}+}$. Reagent solutions. FOX (Ferrous Oxidation in Xylenol orange) assay reagents. In a plastic vial (glass vials may leak $\mathrm{Fe}^{3+}$ ), $3.644 \mathrm{~g}$ sorbitol (final $2 \mathrm{M}$, and in assay reaction $0.1 \mathrm{M}$ ) and $15.2 \mathrm{mg}$ xylenol orange are dissolved (for about $30 \mathrm{~min}$ ) in $7.6 \mathrm{ml} 0.66 \mathrm{M} \mathrm{HClO}_{4}$ (final $0.5 \mathrm{M}$, and in assay reaction $25 \mathrm{mM}$ ). Then, any non-dissolved matter is removed by centrifugation (or by filtering), the resulting supernatant is split in two halves $\left(5 \mathrm{ml}\right.$ each), and one half is the FOX-Fe ${ }^{2+}$ reagent. To the other half, $7.9 \mathrm{mg}$ ferrous ammonium sulfate are dissolved, resulting in the $\mathrm{FOX}+\mathrm{Fe}^{2+}$ reagent. Both the reagents are prepared fresh.

$0.1 \mathrm{M}$ EDTA stock. It is prepared in $\mathrm{ddH}_{2} \mathrm{O}$. EDTA is a $\mathrm{Fe}^{3+}$ chelator, and is used here as blank for the estimation of soil $\mathrm{Fe}^{3+}$.

Standard curves. $\mathrm{H}_{2} \mathrm{O}_{2}(0-2 \mu \mathrm{M})$ standard curve. It is made with a $4 \mu \mathrm{M} \mathrm{H}_{2} \mathrm{O}_{2}$ solution (in $10 \mathrm{mM}$ phosphate buffer, $\mathrm{pH}$ 6.5) prepared from a $5 \mathrm{mM} \mathrm{H}_{2} \mathrm{O}_{2}$ working stock, which is made from the concentrated $30 \% \mathrm{H}_{2} \mathrm{O}_{2}$ using the $\mathrm{H}_{2} \mathrm{O}_{2}$ molar extinction coefficient at $240 \mathrm{~nm}\left(\varepsilon_{240}=43.6 \mathrm{M}^{-1} \mathrm{~cm}^{-1}\right)$. The reagents are mixed as presented in the following box:

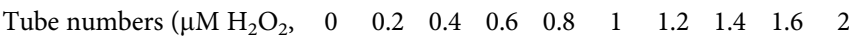
or $\mathrm{nmol} \mathrm{H}_{2} \mathrm{O}_{2}$ in $1 \mathrm{ml}$

assay reaction). Reagents in $\mu \mathrm{l}$

$4 \mu \mathrm{M} \mathrm{H}_{2} \mathrm{O}_{2}$ $\begin{array}{llllllllll}0 & 50 & 100 & 150 & 200 & 250 & 300 & 350 & 400 & 500\end{array}$ $10 \mathrm{mM}$ phosphate buffer, $950 \quad 900 \quad 850 \quad 800 \quad 750 \quad 700 \quad 650 \quad 600 \quad 550 \quad 450$ pH 6.5

$\mathrm{FOX}+\mathrm{Fe}^{2+}$ reagent

$50 \mu \mathrm{l}$ in each tube

Each tube is then incubated for $30 \mathrm{~min}$ at RT after which the absorbance at $560 \mathrm{~nm}$ $\left(A_{560 \mathrm{~nm}}\right)$ of each of the assay reaction mixtures in tubes $0-2$ is measured. The net $A_{560 \mathrm{~nm}}$ value of tubes $0.2-2$ is calculated by subtracting from their $A_{560 \mathrm{~nm}}$ value the $A_{560 \mathrm{~nm}}$ value of tube 0 (the blank). Then, the standard curve is drawn by plotting the $0-2 \mu \mathrm{M}$ (or nmoles) $\mathrm{H}_{2} \mathrm{O}_{2}$ against their corresponding net $A_{560 \mathrm{~nm}}$ values.

NOTE: With $10 \mathrm{mM}$ phosphate, $\mathrm{pH} 6.5$, as $\mathrm{H}_{2} \mathrm{O}_{2}$ /sample solvent, the final $25 \mathrm{mM}$ perchloric acid in the assay achieves assay reaction $\mathrm{pH} \sim 1.8$. At these conditions, the assay achieves its highest, for $\mathrm{H}_{2} \mathrm{O}_{2}$, molar extinction coefficient $\sim 250,000 \mathrm{M}^{-1} \mathrm{~cm}^{-1}$ ). With unbuffered samples (that is, in $\mathrm{H}_{2} \mathrm{O}$ ), the final concentration of perchloric acid in the assay should be $15.5 \mathrm{mM}\left(\right.$ in $^{+}$), which corresponds to the optimal assay $\mathrm{pH} 1.8$.

$\mathbf{F e}^{3+}(\mathbf{0}-12 \mu \mathbf{M})$ standard curve. It is made from a $20 \mu \mathrm{M} \mathrm{Fe}{ }^{3+}$ stock solution (in $10 \mathrm{mM}$ phosphate buffer, $\mathrm{pH}$ 6.5). The reagents are mixed as presented in the following box:

\begin{tabular}{lllllllll}
\hline $\begin{array}{l}\text { Tube numbers }\left(\mu \mathrm{M} \mathrm{Fe}^{3+},\right. \\
\text { or nmol } \mathrm{Fe}^{3+} \text { in } 1 \mathrm{ml} \text { assay } \\
\text { reaction). Reagents in } \mu \mathrm{l}\end{array}$ & 0 & 1 & 2 & 4 & 6 & 8 & 10 & 12 \\
\end{tabular}

$20 \mu \mathrm{M} \mathrm{Fe}^{3+}$ (in $10 \mathrm{mM}$ phosphate $0 \quad 50 \quad 100 \quad 200300400 \quad 500 \quad 600$ buffer, $\mathrm{pH}$ 6.5)

$10 \mathrm{mM}$ phosphate buffer, pH $6.5 \quad 950 \quad 900 \quad 850 \quad 750 \quad 650 \quad 550 \quad 450 \quad 350$ FOX-Fe ${ }^{2+}$ reagent 50 in each tube

Each tube is then incubated for $30 \mathrm{~min}$ at RT after which the absorbance at $560 \mathrm{~nm}$ $\left(A_{560 \mathrm{~nm}}\right)$ of each of the assay reaction mixtures in tubes $0-12$ is measured. The net $A_{560 \mathrm{~nm}}$ value of tubes 1-12 is calculated by subtracting from their $A_{560 \mathrm{~nm}}$ value the $A_{560 \mathrm{~nm}}$ value of tube 0 (the blank). Then, the standard curve is plotted as $0-12 \mu \mathrm{M}$ (or nmoles) Fe $\mathrm{Fe}^{3}$ against their corresponding net $A_{560 \mathrm{~nm}}$ values.

Protocol. Soil samples were treated as follows: $1 \mathrm{~g}$ soil (placed in a capped 15-ml plastic centrifuge tube) was extracted in (for example, 1-4 ml) $10 \mathrm{mM} \mathrm{H}_{3} \mathrm{PO}_{4}$ for 2 min by gentle inversion and the soil extract was collected by centrifugation at $5,000 \mathrm{~g}$ for $5 \mathrm{~min}$.

NOTE: Extraction of the Mojave and Atacama soil samples with $10 \mathrm{mM} \mathrm{H}_{3} \mathrm{PO}_{4}$ resulted in $\mathrm{pH} \sim 6.5$ of the soil $\mathrm{H}_{2} \mathrm{O}_{2}$ extract.

The soil extract (its $\mathrm{pH}$ is adjusted to $\sim 6.5$ with $0.1 \mathrm{M} \mathrm{NaOH} / \mathrm{HCl}$ if needed) was treated with the assay reagents (in $1.5-\mathrm{ml}$ microcentrifuge tubes) shown as presented in the following box:
Sample treatments (STs) and reagent

ST1 ST2 ST3 ST4 RB1 RB2 blanks (RBs): Reagents in $\mu \mathrm{l}$

Soil extract (or appropriate dilutions in $935935935935 \quad-\quad$ $10 \mathrm{mM}$ phosphate buffer, $\mathrm{pH}$ 6.5)

$10 \mathrm{mM}$ phosphate buffer, pH 6.5

$3 \mathrm{KU} \mathrm{ml}^{-1}$ CAT (in $10 \mathrm{mM}$ phosphate $15-15-950$ - 15

buffer, $\mathrm{pH}$ 6.5)

5-min incubation

$0.1 \mathrm{M}$ EDTA

1 -min incubation

$\mathrm{FOX}+\mathrm{Fe}^{2+}$ reagent

FOX-Fe ${ }^{2+}$ reagent

$\begin{array}{ccccccc}- & 15 & - & - & - & 15 \\ \text { No } & \text { Yes } & \text { No } & \text { No } & \text { No } & \text { Yes } \\ - & - & - & 15 & - & - \\ \text { No } & \text { No } & \text { No } & \text { Yes } & \text { No } & \text { No } \\ 50 & 50 & - & - & 50 & 50 \\ - & - & 50 & 50 & - & -\end{array}$

After mixing, the ST1, ST2, ST3, ST4, RB1 and RB2 tubes are incubated for 30 min at RT. NOTE: For higher accuracy, ST1, ST2, ST3 and ST4 mixtures are preferably made each in triplicates from three different soil extract dilutions, while RB1 and RB2 are made in triplicates.

The corresponding $\mathrm{A}_{\mathrm{ST} 1}, \mathrm{~A}_{\mathrm{ST} 2}, \mathrm{~A}_{\mathrm{ST} 3}, \mathrm{~A}_{\mathrm{ST} 4}, \mathrm{~A}_{\mathrm{RB} 1}$ and $\mathrm{A}_{\mathrm{RB} 2}$ absorbance values are recorded at $560 \mathrm{~nm}$, and their triplicate averages are then entered in the following equations to calculate the corresponding net $A_{560 \mathrm{~nm}}$ for soil $\mathrm{H}_{2} \mathrm{O}_{2}$ and $\mathrm{Fe}^{3+}$, which are then converted to $\mathrm{H}_{2} \mathrm{O}_{2}$ and $\mathrm{Fe}^{3+}$ concentrations (from the corresponding standard curves), expressed per g soil:

$$
\begin{gathered}
\text { Soil } \mathrm{H}_{2} \mathrm{O}_{2} \text { net } A_{560 \mathrm{~nm}}=\mathrm{A}_{\mathrm{ST} 1}-\mathrm{A}_{\mathrm{ST} 2}+\left(\mathrm{A}_{\mathrm{RB} 2}-\mathrm{A}_{\mathrm{RB} 1}\right) \\
\text { Soil Fe }{ }^{3+} \text { net } \mathrm{A}_{560 \mathrm{~nm}}=\mathrm{A}_{\mathrm{ST} 3}-\mathrm{A}_{\mathrm{ST} 4}
\end{gathered}
$$

Instability of aqueous desert soil superoxides/peroxides. To test whether the instability of soil $\mathrm{H}_{2} \mathrm{O}_{2}$ extracts (from total metal peroxides) during various incubation intervals concurs with the generation of ${ }^{\prime} \mathrm{OH}$ radicals, these were trapped in the $\mathrm{H}_{2} \mathrm{O}_{2}$ extracts by TPA and the resulting specific fluorescent product 2-hydroxyl terephthalate (HTPA) was isolated and quantified by the following procedured developed for this study.

Procedure: Soil $\mathrm{H}_{2} \mathrm{O}_{2}$ extracts were analysed for stability and $\mathrm{OH}$ generation versus extract incubation time $(0-48 \mathrm{~h})$ in the absence $(\mathrm{A})$ and presence $(\mathrm{B})$ of the extracted soil. Specifically, $\mathrm{H}_{2} \mathrm{O}_{2}$ was extracted from two 1-g soil samples (per incubation time interval) after each was mixed with $4 \mathrm{ml} 10 \mathrm{mM} \mathrm{H}_{3} \mathrm{PO}_{4}$ for $5 \mathrm{~min}$ at RT, followed by centrifugation at $4,200 \mathrm{~g}$ for $3 \mathrm{~min}$. The $\mathrm{H}_{2} \mathrm{O}_{2}$ extract in the isolated supernatant (in the absence of the soil precipitate) was kept for treatment $\mathrm{A}$ and that in the upper aqueous phase (in the presence of the soil precipitate) was kept for treatment B. Stability of $\mathrm{H}_{2} \mathrm{O}_{2}$ in extract samples from treatment A was measured as the remaining $\mathrm{H}_{2} \mathrm{O}_{2}$ concentration after certain incubation time intervals (up to $48 \mathrm{~h}$ ) at RT, using as control a solution of $2 \mu \mathrm{M} \mathrm{H}_{2} \mathrm{O}_{2}$ in $10 \mathrm{mM}$ $\mathrm{H}_{3} \mathrm{PO}_{4}$ (made from the $30 \% \mathrm{H}_{2} \mathrm{O}_{2}$, the preparation of which is described in the $\mathrm{H}_{2} \mathrm{O}_{2}$ standard curve presented in the Methods section 'Assay for soil total metal superoxides/peroxides and $\mathrm{Fe}^{3+}$ ). The concentration of $\mathrm{H}_{2} \mathrm{O}_{2}$ was measured as described in the Methods section 'Assay for soil total superoxides/peroxides and $\mathrm{Fe}^{3+}$. More experimental details are also presented in the legend of Fig. 1. To measure the generation of $\mathrm{OH}$ in the extracts of treatments $\mathrm{A}$ and $\mathrm{B}$, they were both brought to $2 \mathrm{mM}$ TPA (from a $100 \mathrm{mM}$ TPA stock made by dissolving $115 \mathrm{mg}$ TPA in $1.4 \mathrm{ml} 1 \mathrm{M} \mathrm{NaOH}$ and then mixing with $1.4 \mathrm{ml} 50 \mathrm{mM}$ phosphate buffer, $\mathrm{pH}$ 7.4, readjusted with $1 \mathrm{M} \mathrm{HCl}$ and $\mathrm{ddH}_{2} \mathrm{O}$ to final $7 \mathrm{ml}$ ) and incubated at $\mathrm{RT}$ in the dark for the selected time intervals. As control, corresponding soil extracts were also incubated with $100 \mathrm{mM}$ DMSO), an $\mathrm{OH}$ scavenger. After each incubation period, $0.9 \mathrm{ml}$ of the soil extracts for treatments A and B were mixed with $9 \mu \mathrm{l} 10 \mathrm{M}$ $\mathrm{NaOH}$ (to ensure deprotonation of HTPA) and washed with an equal volume ethyl acetate-ethanol (2:1) by vortexing, followed by centrifugation at $4,200 \mathrm{~g}$ for $5 \mathrm{~min}$ The resulting bottom aqueous phase $(\sim 1.2 \mathrm{ml})$ was acidified by $25 \mu \mathrm{l} 10 \mathrm{M} \mathrm{HCl}$ (to protonate HTPA) and HTPA (and TPA) was extracted (by vortexing) with two $0.9-\mathrm{ml}$ ethyl acetate washes, followed by centrifugation for $5 \mathrm{~min}$ at $4,200 \mathrm{~g}$. The combined $1.8 \mathrm{ml}$ ethyl acetate phase was washed with $1.8 \mathrm{ml} 0.1 \mathrm{M} \mathrm{HCl}$ and evaporated in a rotary vacuum concentrator. The resulting solid precipitate was dissolved in $15 \mathrm{mM} \mathrm{KOH}$ (at a minimum volume for example, $\sim 0.1 \mathrm{ml}$ ) and adjusted to $\mathrm{pH} 7$ (with $0.2 \mathrm{M} \mathrm{KH}_{2} \mathrm{PO}_{4}, \mathrm{pH}$ 7) for high-performance liquid chromatography (HPLC) analysis. Samples $(10 \mu \mathrm{l})$ were injected into an Shimadzu HPLC Prominence UFLC system, consisting of a solvent delivery system (model LC-20AD), a sample manual injector (Rheodyne 7725i), an on-line degasser (DGU-20A5), a reverse-phase C18 column (Waters Nova-Pak C18, $60 \AA$, $4 \mu \mathrm{m}$, $3.9 \times 150 \mathrm{~mm}$ ) and a fluorescent detector (RF-20Axs) set at ex/em $311 / 425 \mathrm{~nm}$. The mobile phase, consisting of $50 \mathrm{mM} \mathrm{KH}_{2} \mathrm{PO}_{4}$ in $30 \%$ methanol, pH 3.2 (an alternative mobile phase is $0.2 \mathrm{M} \mathrm{KH}_{2} \mathrm{PO}_{4}, \mathrm{pH} 4.37$, containing $2 \%$ of $\mathrm{KCl}^{70}$ ), was passed through the column at a flow rate $0.8 \mathrm{ml} \mathrm{min}^{-1}$ and the sample was eluted for a total of $20 \mathrm{~min}$. HTPA in samples was identified and quantified by HPLCfluorescence (eluted as a peak at $\sim 14 \mathrm{~min}$ ) against pure HTPA (article Fig. 1b), which was synthesized as reported in the Supplementary Methods. HTPA was also identified by mass spectroscopy using an Agilent 1260 Infinity HPLC-MS system equiped with a binary pump, an auto-sampler and a micro-column Zorbax Extend- 
C18 600Bar $2.1 \times 50 \mathrm{~mm}, 1.8 \mu \mathrm{M}$, connected on line with an Agilent $6538 \mathrm{UHD}$ Accurate-Mass Q-TOF LC/MS detector, operated in negative (ESI ${ }^{-}$) electrospray ionization mode. Samples $(10 \mu \mathrm{l})$ were eluted under linear gradient conditions (at a flow rate $0.3 \mathrm{ml} \mathrm{min}^{-1}$ for $10 \mathrm{~min}$ ) at RT, by an increasing $100 \% \mathrm{ACN}$ (solvent A) and a decreasing $50 \mathrm{mM} \mathrm{KH}_{2} \mathrm{PO}_{4}, \mathrm{pH} 3.2,30 \% \mathrm{MetOH}$ (solvent B) mobile solvent phase. The microcolumn was initially washed with the A and subsequently equilibrated with the solvent B. HTPA (eluted as a peak at $\sim 1.5 \mathrm{~min}$ ) was identified as giving, for the parent ion, $m / z$ with highest peak at M- $1=181.01437$ (versus the theoretical 181.01425), and a fragmentation product at $\mathrm{M}-1=137.02442$ (expected from the fragmentation, at $\mathrm{CE} 20 \mathrm{eV}$, of one carboxyl group from HTPA).

Soil $\mathbf{O}_{\mathbf{2}}{ }^{-}$generation by sunlight and ultraviolet-C. Procedure: Soils $(\sim 1 \mathrm{~g})$, untreated or washed (to remove any soluble inorganics/organics and polar/ hydrophobic organics by vortexing (and intermittent centrifugation at 4,200g for $5 \mathrm{~min}$ ) with $2 \times 10 \mathrm{ml} 0.1 \mathrm{M} \mathrm{HCl}, 1 \times 10 \mathrm{ml} \mathrm{ddH}_{2} \mathrm{O}, 2 \times 10 \mathrm{ml} 0.1 \mathrm{M} \mathrm{NaOH}$, $3 \times 10 \mathrm{ml} \mathrm{ddH_{2 }} \mathrm{O}, 2 \times 5 \mathrm{ml} \mathrm{ddH}_{2} \mathrm{O}$ plus $5 \mathrm{ml}$ ethyl acetate:ethanol $(2: 1), 1 \times 10 \mathrm{ml}$ $25 \%$ ethanol, and finally dried at $150^{\circ} \mathrm{C}$ for $1 \mathrm{~h}$ ) were spread as a thin layer on aluminum foil and exposed to natural sunlight (at $800-1,000 \mathrm{~W} \mathrm{~m}^{-2}$, in a July day, from 10:00 to 16:00 hours and at an average $45^{\circ} \mathrm{C}$ ); unexposed were used as control. The relative humidity at 10:00 hours was $\sim 15 \%$ and reached a minimum $\sim 5 \%$ during the exposure period. Soils were also exposed to iltraviolet $\mathrm{C}$ radiation (using a germicidal lamp with flux density $30 \mu \mathrm{W} \mathrm{cm}{ }^{-2}$ set at a close distance of $10 \mathrm{~cm}$ ) at relative humidity $10-25 \%$ and at an average $40^{\circ} \mathrm{C}$. After irradiation, soils were extracted for $\mathrm{O}_{2}{ }^{-}$(as in the Methods section 'HE-based soil $\mathrm{O}_{2}{ }^{-}$assay') and measured by the aforementioned HE-based and SOD-inhibited reduction of cyt. $c$-based soil $\mathrm{O}_{2}{ }^{-}$assays. Irradiated soils were also extracted for total superoxides/ peroxides and the resulting $\mathrm{H}_{2} \mathrm{O}_{2}$ extract was measured as in the Methods section 'Assay for soil total metal superoxides/peroxides and $\mathrm{Fe}^{3+}$ '.

Photo-generation of ' $\mathrm{OH}$ by aqueous desert soils. Procedure: Soil samples were extensively washed as in the Methods section 'Soil $\mathrm{O}_{2}{ }^{-}$generation by sunlight and ultraviolet C' to remove any soluble inorganic/organic and polar/hydrophobic organic soil constituents, which may affect the rate of photogeneration of ${ }^{\prime} \mathrm{OH}$. Washed soil samples $(0.2 \mathrm{~g})$ were placed in capped small plastic Petri plates (inner

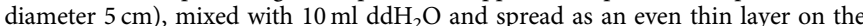
plate bottom with a small glass rod. Then, $50 \mu \mathrm{l}$ from the $100 \mathrm{mM}$ TPA stock solution (made in $400 \mathrm{mM} \mathrm{NaOH}$ ) was added. This resulted in final $0.5 \mathrm{mM}$ TPA and $1 \mathrm{mM} \mathrm{NaOH}$ (due to its partial neutralization by the $1 \mathrm{mM}$ carboxyl groups of $0.5 \mathrm{mM}$ TPA), which were set as an optimal for the ${ }^{\circ} \mathrm{OH}$-TPAassay in a previous study using illuminated $\mathrm{TiO}_{2}$ films ${ }^{37,38}$. Samples were exposed to light irradiation $180 \mathrm{~W} \mathrm{~m}^{-2}$ (at $400-800 \mathrm{~nm}$, emitted by two halogen lamps, type R7s J118 tube linear $500 \mathrm{~W} / 230 \mathrm{~V} \sim 9000$ Lumens per $\mathrm{m}^{2}$ each, both covered with glass and ultraviolet and infrared cutoff filters and set at $50 \mathrm{~cm}$ above the soil plates) or higher (adding more lamps) and for up to $10 \mathrm{~h}$ (at RT). The following lightexposed controls were used: (a) soil samples mixed with $10 \mathrm{ml} 1 \mathrm{mM} \mathrm{NaOH}$ (for soil interference), (b) $10 \mathrm{ml} 1 \mathrm{mM} \mathrm{NaOH}$ (for aqueous phase treatment interference), (c) $10 \mathrm{ml} 0.5 \mathrm{mM} \mathrm{TPA}$ and $2 \mathrm{mM} \mathrm{NaOH}$ (for TPA interference) $\pm 100 \mathrm{mM}$ DMSO (' $\mathrm{OH}$ scavenger), (d) $10 \mathrm{ml} 1 \mu \mathrm{M} \mathrm{H}_{2} \mathrm{O}_{2}$ in $0.5 \mathrm{mM}$ TPA and $2 \mathrm{mM} \mathrm{NaOH}$ (to test possible photolysis of $\mathrm{H}_{2} \mathrm{O}_{2}$ to $\mathrm{OH}$; both can be products of, for example, $\mathrm{TiO}_{2}$ photocatalysis ${ }^{38}$, given that $\mathrm{H}_{2} \mathrm{O}_{2}$ can be generated directly or indirectly, for example, via dismutation, from $\mathrm{O}_{2}{ }^{-}$) and (e) $10 \mathrm{ml}$ suspension of $1.6 \mathrm{mg} \mathrm{TiO}_{2}$ (or $20 \mu \mathrm{M} \mathrm{TiO}_{2}$ ) in $0.5 \mathrm{mM} \mathrm{TPA}$ and $2 \mathrm{mM} \mathrm{NaOH}$ (for testing the employed assay to detect ${ }^{\circ} \mathrm{OH}$ photo-generation and by simulating a photocatalysis mechanism with $\mathrm{TiO}_{2}$ ). The amount of $\mathrm{TiO}_{2}$ used is equivalent to the average concentration $(\mathrm{w} \%)$ in the $0.2 \mathrm{~g}$ soils from Atacama Yungay and Mojave + CIMA sites (Table 2). Exposure of the soil samples to ultraviolet $\mathrm{C}$ irradiation was not used because the control (c) produced ${ }^{\circ} \mathrm{OH}$, possibly because the ultraviolet C lamp may also emit near the absorbance of water $(186 \mathrm{~nm})$ and, thus, photo-dissociate it to $\mathrm{OH}$. Aqueous samples $(1 \mathrm{ml})$ were drawn from the plates at certain time intervals, centrifuged at $16,000 \mathrm{~g}$ for $5 \mathrm{~min}$ at RT, acidified with final $0.1 \mathrm{M} \mathrm{HCl}$, extracted $\times 2$ with $1 \mathrm{ml}$ ethyl acetate (by vortexing and subsequent centrifugation at $4,000 \mathrm{~g}$ ) and dried by a centrifugal vacuum concentrator at $50^{\circ} \mathrm{C}$. The isolated HTPA solid precipitate in soil and control samples was dissolved in $0.1 \mathrm{ml} 20 \mathrm{mM} \mathrm{NaOH}$ (its moles are $\times 2$ those of the total carboxy groups of added TPA) and neutralized by $0.2 \mathrm{ml} 150 \mathrm{mM}$ K-phosphate buffer, pH 7.4. The solubilized HTPA was quantified by HPLC-fluorescence (as in the Methods section 'Instability of aqueous desert soil superoxides/peroxides'), and, in routine HTPA quantifications by measuring the fluorescence difference emission spectra (recorded at the excitation wavelength $311 \mathrm{~nm}$ ) of samples minus those of appropriate controls as follows: Starting with the determination of the emission spectra of controls (a) and (b), they were found identical (indicating that washed soil did not interfere) and lower in FUs than of the control (c) spectrum, which shows that both the controls were part of the control (c). Therefore, the emission spectrum of latter control was subtracted from the soil sample emission spectra taken at different exposure time periods, to estimate the corresponding net emission spectra due to HTPA present in the samples. These HTPA spectra were identified by comparing their shape and peak at $425 \mathrm{~nm}$ with the spectra of pure HTPA (synthesized as in the Methods section 'Instability of aqueous desert soil superoxides/peroxides'), and with the known emission spectra of HTPA, which are stable at a pH range 5.5-9.5 (ref. 70). Similarly, the control (c) emission spectrum was subtracted from the emission spectra of controls (d) and (e) to identify the formation of HTPA due to $\mathrm{H}_{2} \mathrm{O}_{2}$ and $\mathrm{TiO}_{2}$, respectively. The net $\mathrm{FU}$ emission peak (at $425 \mathrm{~nm}$ with excitation at $311 \mathrm{~nm}$ ) in the difference spectra was, then, converted to HTPA concentration by a spectrofluorometer (Shimadzu RF-1501) calibrated with $1 \mu \mathrm{M}$ pure HTPA; it emits $\sim 300 \mathrm{FU}$ at the spectrofluorometer's low sensitivity setting (or 15,000 FU at the high-sensitivity setting). Additional data analysis is presented in the corresponding section of the Supplementary Methods.

Mineralogical and geochemical analysis of soils. Procedure: The bulk mineralogy of the samples was determined by X-ray diffraction on the D8 Advance diffractometer (Bruker AXS) equipped with a LynxEye strip silicon detector, using $\mathrm{Ni}$-filtered $\mathrm{CuK} \alpha$ radiation, an applied voltage $35 \mathrm{kV}$ and a $35 \mathrm{~mA}$ current, and $0.298^{\circ}$ divergence and antiscatter slits. The random powder mounts of samples were scanned from 2 to $70^{\circ} 2 \theta$ with a scanning step of $0.015^{\circ} 2 \theta$ and with 18.7-s count time per step. Powder diffraction data were collected at RT. Results were confirmed with synchrotron X-ray high-resolution powder diffraction measurements. The samples were loaded into $1.0 \mathrm{~mm}$-diameter glass capillaries. Powder diffraction data (for Atacama Yungay and site 1, and Mojave + CIMA basalt rock samples) were collected at RT ( $295 \mathrm{~K}$ ) on the undulator beamline ID31 at the ESRF (European Synchrotron Radiation Facility) in Grenoble, France. The parallel beam geometry instrument is equipped with nine $\mathrm{Si}(111)$ analyser crystals and provides data with very high angular resolution, with a minimum instrumental contribution to the full-width half-maximum around $0.003^{\circ}$. High speed spinning of the sample was applied to ensure sufficient powder averaging. The nine detector modules (separated by $\sim 2^{\circ}$ ) were scanned over a $40^{\circ} 2 \theta$ range, at a wavelength of $0.400054(15) \AA$, using an incident beam size of $2.0 \mathrm{~mm}$ ( $2.0 \mathrm{~mm}$ (horizontally) $\times 1.0 \mathrm{~mm}$ (vertically)). The clay fraction $(<2 \mu \mathrm{m})$ was separated by settling and dried on glass slides at RT. Clay minerals were identified from air dried slides and after ethylene glycol solvation at $60^{\circ} \mathrm{C}$ overnight to ensure maximum saturation. $\mathrm{X}$-ray diffraction analysis was performed from 2 to $35^{\circ} 2 \theta$ with the Bruker D8 Advance diffractometer, using the same divergence and antiscatter slits, and a step size of $0.019^{\circ} 2 \theta$, with $47.7-\mathrm{s}$ count time per step. Chemical composition of minerals was examined with a JEOL 6300 Scanning Electron Microscope equipped with an Oxford Link Energy Dispersive Spectrometer (EDS; Oxford Instruments). Semi-quantitative analyses of minerals were performed on sample powders mounted directly on glass slides and coated with carbon. The chemical composition of the minerals was determined using natural and synthetic standards and $20 \mathrm{kV}$ accelerating voltage with $10 \mathrm{nA}$ beam current. Back-scattered electron images were used to identify any heavy minerals present. The concentrations of major and trace elements in bulk samples (from Atacama sites, Mojave sites and control site) were determined with Energy Dispersive X-ray Florescence Spectroscopy (EDS-XRF, S2 Ranger, Bruker). The samples were fused using a flux:sample powder ratio of 5:1 and were casted in dies forming glass beads. Li-tetraborate was used as flux. Additional data analyses can be found in the corresponding section of the Supplementary Methods.

\section{References}

1. Navarro-Gonzalez, R et al. Mars-like soils in the Atacama desert, Chile, and the dry limit of microbial life. Science 302, 1018-1021 (2003).

2. Quinn, R. C., Ehrenfreund, P, Grunthaner, F. J., Taylor, C. L. \& Zent, A. P. Decomposition of aqueous organic compounds in the Atacama Desert and in Martian soils. J. Geophs. Res. 112, G04S18 (2007).

3. McCalley, C. K. \& Sparks, J. P. Abiotic gas formation drives nitrogen loss from a desert ecosystem. Science 326, 837-840 (2009).

4. Austin, A. T. \& Vivanco, L. Plant litter decomposition in a semi-arid ecosystem controlled by photodegradation. Nature 442, 555-558 (2006).

5. Gohre, K \& Miller, G. C. Singlet oxygen generation on soil surfaces. J. Agric. Food Chem. 31, 1104-1108 (1983).

6. Katagi, T. Photodegradation of 3-phenoxybenzoic acid in water and on solid surfaces. J. Agric. Food Chem. 40, 1269-1274 (1992).

7. Misra, B, Graebing, P. W. \& Chib, J. S. Photodegradation of chloramben on a soil surface: a laboratory-controlled study. J. Agric. Food Chem. 45, 1464-1467 (1997).

8. Hebertt, V. R. \& Miller, G. C. Depth dependence of direct and indirect photolysis on soil surfaces. J. Agric. Food. Chem. 38, 913-918 (1990).

9. Frank, M. P., Graebing, P \& Chib, J. S. Effect of soil moisture and sample depth on pesticide photolysis. J. Agric. Food Chem. 50, 2607-2614 (2002).

10. Katagi, K. Photodegradation of pesticides on plant and soil surfaces. Rev. Environ. Contam. Toxicol. 182, 1-195 (2004).

11. Suzuki, Y, Lopez, A, Ponte, M, Fujisawa, T, Ruzo, L. O. \& Katagi, T. Photoinduced oxidation of the insecticide phenothrin on soil surfaces. J. Agric Food Chem. 59, 10182-10190 (2011).

12. Halliwell, B \& Gutteridge, C. M. J. Free Radicals in Biology and Medicine 3rd edn (Oxford Univ. Press, 1999).

13. Lunsford, J. H. ESR of adsorbed oxygen species. Catal. Rev. 8, 135-157 (1973).

14. Che, $\mathrm{M} \&$ Tench, A. J. Characterization and reactivity of molecular oxygen species on oxide surfaces. Adv. Catal. 32, 1-148 (1983) 
15. Linsebigler, A. L., Lu, G \& Yates, J. T.. J. Photocatalysis on $\mathrm{TiO}_{2}$ surfaces: principles, mechanisms, and selected results. Chem. Rev. 95, 735-758 (1995).

16. Ito, T, Kato, M, Toi, K, Shirakawa, T, Ikemoto, I \& Tokuda, T. Oxygen species adsorbed on ultraviolet-irradiated magnesium oxide. J. Chem. Soc., Faraday Trans. 1 81, 2835-2844 (1985).

17. Yen, A. S., Kim, S. S., Hecht, M. H., Frant, M. S. \& Murray, B. Evidence that the reactivity of the Martian soil is due to superoxide ions. Science 289, 1909-1912 (2000).

18. Gohre, K, Scholl, R \& Miller, G. C. Singlet oxygen reactions on irradiated soil surfaces. Environ. Sci. Technol. 20, 934-938 (1986).

19. Gohre, K \& Miller, G. C. Photochemical generation of singlet oxygen on non-transition-metal oxide surfaces. J. Chem. Soc., Faraday Trans. 1 81, 793-800 (1985).

20. Feng, W \& Nansheng, D. Photochemistry of hydrolytic iron (III) species and photoinduced degradation of organic compounds. A minireview. Chemosphere 41, 1137-1147 (2000).

21. McKay, C. P., Friedmann, E. I., Gómez-Silva, B, Cáceres, L, Andersen, D. T. \& Landheim, R. Temperature and moisture conditions for life in the extreme arid region of the Atacama Desert: four years of observations including the El Niño of 1997-98. Astrobiology 3, 393-406 (2003).

22. Anderson, K, Wells, S \& Graham, R. Pedogenesis of vesicular horizons, Cima Volcanic Field, Mojave Desert, California. Soil Sci. Soc. Am. J. 66, 878-887 (2002).

23. Georgiou, C. D., Papapostolou, I \& Grintzalis, K. Superoxide radical detection in cells, tissues, organisms (animals, plants, insects, microorganisms) and soils. Nat. Protoc. 3, 1679-1692 (2008).

24. Georgiou, C. D., Papapostolou, I, Sun, H \& McKay, C. P. Superoxide radical assays and applications in Mars-like Atacama soils. J Geophys. Res. 112, G04S13 (2007).

25. McCord, M. J. \& Fridovich, I. Superoxide dismutase: an enzymic function for erythrocuprein (hemocuprein). J. Biol. Chem. 244, 6049-6055 (1969).

26. Hyland, K \& Auclair, C. The formation of superoxide radical anions by a reaction between $\mathrm{O}_{2}, \mathrm{OH}^{-}{ }^{-}$and dimethyl sulfoxide. Biochem. Biophys. Res. Com. 102, 531-537 (1981).

27. Sharma, K. S. Inorganic Reaction Mechanisms (Discovery Publishing House, 2007).

28. Makarov, S. Z. \& Ladelnova, L. V. The peroxides of titanium, zirconium, and cerium formed in the reaction of their hydroxides with hydrogen peroxide. Russian Chem. Bull. 10, 889-893 (1961).

29. Grintzalis, K, Zisimopoulos, D, Grune, T, Weber, D \& Georgiou, C. D. Method for the simultaneous determination of free/protein malondialdehyde and lipid/protein hydroperoxides. Free Rad. Biol. Med. 59, 27-35 (2013).

30. Perez-Benito, J. F. Iron(III)-hydrogen peroxide reaction: kinetic evidence of a hydroxyl-mediated chain mechanism. J. Phys. Chem. 108, 4853-4858 (2004)

31. Strlič, M, Kolar, J, Šelih, V-S, Kočar, D \& Pihlar, B. A comparative study of several transition metals in Fenton-like reaction systems at circum-neutral $\mathrm{pH}$. Acta Chim. Slov. 50, 619-632 (2003).

32. Iuga, K, Olea, R. E. \& Vivier-Bunge, A. Mechanism and kinetics of the $\mathrm{OH} \bullet$ radical reaction with formaldehyde bound to an $\mathrm{Si}(\mathrm{OH})_{4}$ monomer. J. Mex. Chem. Soc. 51, 36-46 (2008).

33. Buxton, G. V., Greenstock, C. L., Helman, W. P. \& Ross, A. B. Critical review of rate constants for reactions of hydrated electrons, hydrogen atoms and hydroxyl radicals (OH/O) in aqueous solution. J. Phys. Chem. Ref. Data 17, 513-886 (1988).

34. Lybrand, R. A., Michalski, G, Graham, R. C. \& Parker, D. R. The geochemical associations of nitrate and naturally formed perchlorate in the Mojave Desert, California, USA. Geochim. Cosmochim. Acta 104, 136-147 (2013).

35. Michalski, G, Böhlke, J. K. \& Thiemens, M. Long term atmospheric deposition as the source of nitrate and other salts in the Atacama Desert, Chile: new evidence from mass-independent oxygen isotopic compositions. Geochim. Cosmochim. Acta 68, 4023-4038 (2004).

36. Zigah, D, Rodríguez-López, J \& Bard, A. J. Quantification of photoelectrogenerated hydroxyl radical on $\mathrm{TiO}_{2}$ by surface interrogation scanning electrochemical microscopy. Phys. Chem. Chem. Phys. 14, 12764-12772 (2012).

37. Xiao, Q \& Ouyang, L. Photocatalytic activity and hydroxyl radical formation of carbon-doped $\mathrm{TiO}_{2}$ nanocrystalline: effect of calcination temperature. Chem. Eng. J. 148, 248-253 (2009).

38. Ishibashi, K, Fujishima, A, Watanabe, T \& Hashimoto, K. Detection of active oxidative species in $\mathrm{TiO}_{2}$ photocatalysis using the fluorescence technique. Electrochem. Commun. 2, 207-210 (2000).

39. Li, Y.-F. \& Liu, Z.-P. Particle size, shape and activity for photocatalysis on titania anatase nanoparticles in aqueous surroundings. J. Am. Chem. Soc 133, 15743-15752 (2011).

40. Anpo, $\mathrm{M}$ et al. Generation of superoxide ions at oxide surfaces. Top. Catal. 8, 189-198 (1999).

41. Daneshvar, N, Salari, D \& Khataee, A. R. Photocatalytic degradation of azo dye acid red 14 in water on $\mathrm{ZnO}$ as an alternative catalyst to $\mathrm{TiO}_{2}$. J. Photochem. Photobiol. A: Chem. 162, 317-322 (2004).
42. Zent, A. P., Ichimura, A. S., Quinn, R. C. \& Harding, H. K. The formation and stability of the superoxide radical $\left(\mathrm{O}_{2}{ }^{-}\right)$on rock-forming minerals: band gaps, hydroxylation state, and implications for Mars oxidant chemistry. J Geophys. Res. 113, E09001 (2008).

43. Buettner, G. R. The pecking order of free radicals and antioxidants: lipid peroxidation, $\alpha$-tocopherol, and ascorbate. Arch. Biochem. Biophys. 300, 535-543 (1993).

44. Wilson, M. J. Sheet Silicates: Clay minerals. In: Rock-forming minerals (eds Deer, W. A., Howie, R. A. \& Zussman, J) Vol. 3C (The Geological Society, 2013).

45. Stoppato, C \& Bini, A. Deserts (A Firefly Guide) 1st edn (Firefly Books, 2003).

46. Watanabe, N, Kaneko, T, Uchimaru, Y, Yasumori, A \& Sugahara, Y. Preparation of water-dispersible $\mathrm{TiO}_{2}$ nanoparticles from titanium tetrachloride using urea hydrogen peroxide as an oxygen donor. Cryst. Eng. Comm. 15, 10533-10540 (2013).

47. Payne, H. J. \& Foster, L. The action of hydrogen peroxide on carbohydrates. J. Am. Chem. Soc. 67, 1654-1656 (1945).

48. Hall, S. J., Silver, W. L. \& Amundson, R. Greenhouse gas fluxes from Atacama Desert soils: a test of biogeochemical potential at the Earth's arid extreme. Biogeochemistry 111, 303-315 (2012).

49. Milne, P. J. \& Zika, R. G. Amino acid nitrogen in atmospheric aerosols: Occurrence, sources and photochemical modification. J. Atmos. Chem. 16, 361-398 (1993).

50. Patrick, R \& Golden, D. M. Kinetics of the reactions of amidogen radicals with ozone and molecular oxygen. J. Phys. Chem. 88, 491-495 (1984).

51. Crowley, J. N. \& Sodeau, J. R. Reaction between the amidogen radical, $\mathrm{NH}_{2}$, and molecular oxygen in low-temperature matrixes. J. Phys. Chem. 93, 4785-4790 (1989).

52. Sherman, D. M. in Spectroscopic Characterization of Minerals and Their Surfaces (eds Coyne, L. M., Blake, D. F. \& McKeever, S. W. S.) ACS Symposium Series 415 (American Chemical Society, 1989).

53. Venkatachalapathy, R, Davila, G. P. \& Prakash, J. Catalytic decomposition of hydrogen peroxide in alkaline solutions. Electrochem. Commun. 1, 614-617 (1999).

54. Kelly, K. J., Sandoval, R. M., Dunn, K. W., Molitoris, B. A. \& Dagher, P. C. A novel method to determine specificity and sensitivity of the TUNEL reaction in the quantitation of apoptosis. Am. J Physiol. Cell Physiol. 284, C1309-C1318 (2003).

55. Daniel Sheng, G, Xu, C, Xu, L, Qiu, Y \& Zhou, H. Abiotic oxidation of 17beta-estradiol by soil manganese oxides. Environ. Pollut. 157, 2710-2715 (2009).

56. Li, H, Lee, L. S., Schulze, D. G. \& Guest, C. A. Role of soil manganese in the oxidation of aromatic amines. Environ. Sci. Technol. 37, 2686-2693 (2003).

57. Quinn, R. C., Martucci, H. F., Miller, S. R., Bryson, C. E., Grunthaner, F. J. \& Grunthaner, P. J. Perchlorate radiolysis on Mars and the origin of martian soil reactivity. Astrobiology 13, 515-520 (2013).

58. Kounaves, S. P., Carrier, B. L., O’Neil, G. D., Stroble, S. T. \& Clair, M. W Evidence of martian perchlorate, chlorate, and nitrate in Mars meteorite EETA79001: Implications for oxidants and organics. Icarus 229, 206-213 (2014).

59. Smith, M. L., Claire, M. W., Catling, D. C. \& Zahnle, K. J. The formation of sulfate, nitrate and perchlorate salts in the martian atmosphere. Icarus 231, 51-64 (2014)

60. Negron-Encarnacion, I \& Arce, R. Light-induced transformations of aza-aromatic pollutants adsorbed on models of atmospheric particulate matter: Acridine and 9(10-H) acridone. Atmos. Environ. 41, 6771-6783 (2007).

61. Khan, A. U. \& Kasha, M. Singlet molecular oxygen in the Haber-Weiss reaction. Proc. Natl Acad. Sci. USA 91, 12365-12367 (1994).

62. Mao, Y, Zang, L \& Shi, X. Singlet oxygen generation in the superoxide reaction. Biochem. Mol. Biol. Int. 36, 227-232 (1995).

63. Mattimore, V \& Battista, J. R. Radioresistance of Deinococcus radiodurans: functions necessary to survive ionizing radiation are also necessary to survive prolonged desiccation. J. Bacteriol. 178, 633-637 (1996).

64. Daly, M. J. et al. Protein oxidation implicated as the primary determinant of bacterial radioresistance. PLoS Biol. 5, e92 (2007).

65. Oyama, V. I., Berdahl, B. J. \& Carle, G. C. Preliminary findings of the Viking Gas Exchange Experiment and a model for Martian surface chemistry. Nature 265, 110-114 (1977).

66. Klein, H. P. The Viking biological experiments on Mars. Icarus 34, 666-674 (1978).

67. Zent, A. P. \& McKay, C. P. The chemical reactivity of the martian soil and implications for future missions. Icarus 108, 146-457 (1994).

68. Hecht, M. H. et al. Detection of perchlorate and the soluble chemistry of Martian soil at the Phoenix Lander Site. Science 325, 64-67 (2009).

69. Glavin, D. P. et al. Evidence for perchlorates and the origin of chlorinated hydrocarbons detected by SAM at the Rocknest aeolian deposit in Gale Crater. J. Geophs. Res. 118, 1-19 (2013).

70. Linxiang, L et al. An HPLC assay of hydroxyl radicals by the hydroxylation reaction of terephthalic acid. Biomed. Chromatogr. 18, 470-474 (2004). 


\section{Acknowledgements}

C.D.G. was financially supported by the Greek Ministry of Education. H.J.S. and G.Z were supported by a grant from the NASA Astrobiology Program NNX07AT65. H.J.S was also in part supported by the National Science Foundation under grant number IIA-1301726. He thanks R. Kreidberg for editorial assistance. C.P.M. acknowledges the support from the NASA Planetary Protection Program. We thank the ESRF for the provision of synchrotron X-ray beamtime at the high-resolution powder diffraction beamline (ID31). We are grateful to Professor P.V. Ioannou (Department of Chemistry) and Associate Professor M. Kornaros (Department of Chemical Engineering) at the University of Patras, Greece, for HTPA synthesis and HPLC-MS identification in samples, respectively.

\section{Author contributions}

C.D.G., H.J.S. and C.P.M. conceived and designed the experiments, analysed the data contributed materials/analysis tools and co-wrote the paper. C.D.G. conceived the soil

$\mathrm{O}_{2}{ }^{-}$/peroxide and $\mathrm{OH}$ detection assays and experimentally developed and performed them with K.G., I.P., D.Z and K.P. H.J.S. and G.Z. also performed soil peroxide detection experiments. K.G., I.P., D.Z and K.P. had equal contribution in this study. E.K., G.E.C. and I.M. designed and performed the mineralogical experiments, and analysed the relevant data.

\section{Additional information}

Supplementary Information accompanies this paper at http://www.nature.com/ naturecommunications

Competing financial interests: The authors declare no competing financial interests.

Reprints and permission information is available at http://npg.nature.com/ reprintsandpermissions/

How to cite this article: Georgiou, C. D. et al. Evidence for photochemical production of reactive oxygen species in desert soils. Nat. Commun. 6:7100 doi: 10.1038/ncomms8100 (2015). 